
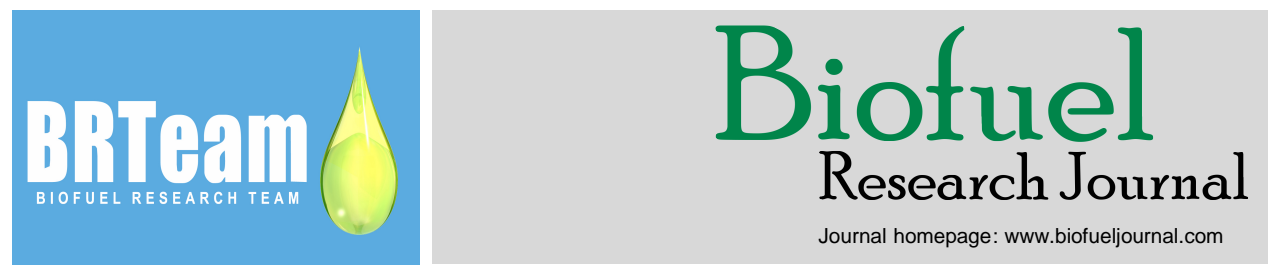

Journal homepage: www.biofueljournal.com

Original Research Paper

\title{
Fossil energy price and outdoor air pollution: predictions from a QUAIDS model
}

\author{
Seyed Reza Khatibi ${ }^{1}$, Seyed M. Karimi ${ }^{2} *$, Maziar Moradi-Lakeh ${ }^{3}$, Majid Kermani ${ }^{4}$, Seyed Abbas Motevalian ${ }^{5}$ \\ ${ }^{1}$ Department of Epidemiology, School of Public Health, Iran University of Medical Sciences, Tehran, Iran. \\ ${ }^{2}$ Department of Health Management and System Sciences, School of Public Health and Information Sciences, University of Louisville, 485 E. Gray St., Room \\ 115, Louisville, Kentucky 40202, USA. \\ ${ }^{3}$ Preventive Medicine and Public Health Research Center \& Department of Community and Family Medicine, Iran University of Medical Sciences, Tehran, \\ Iran. \\ ${ }^{4}$ Research Center for Environmental Health Technology \& Department of Environmental Health Engineering, School of Public Health, Iran University of \\ Medical Science, Tehran, Iran. \\ ${ }^{5}$ Research Center for Addiction and Risky Behaviors (ReCARB), Psychosocial Health Research Institute (PHRI), Department of Epidemiology, School of \\ Public Health, Iran University of Medical Science Tehran, Iran.
}

\section{HIGHLIGHTS}

$>$ Fossil Energy price subsidy encourages overconsumption and elevates air pollution. $>$ A $100 \%$ energy price hike leads to a $29 \%$ decrease in household energy consumption.

$>$ A $100 \%$ energy price hike leads to a 62.9 million ton reduction in air pollutants.

$>$ A $200 \%$ energy price hike leads to a $45 \%$ decrease in household energy consumption.

A $200 \%$ energy price hike leads to a 74.5 million ton reduction in air pollutants.

\section{GRAPHICAL ABSTRACT}

How Shifting Subsidies on Fossil Fuel Prices to Sustainable Sources of Energy, e.g., Biofuels Could Mitigate Air Pollution

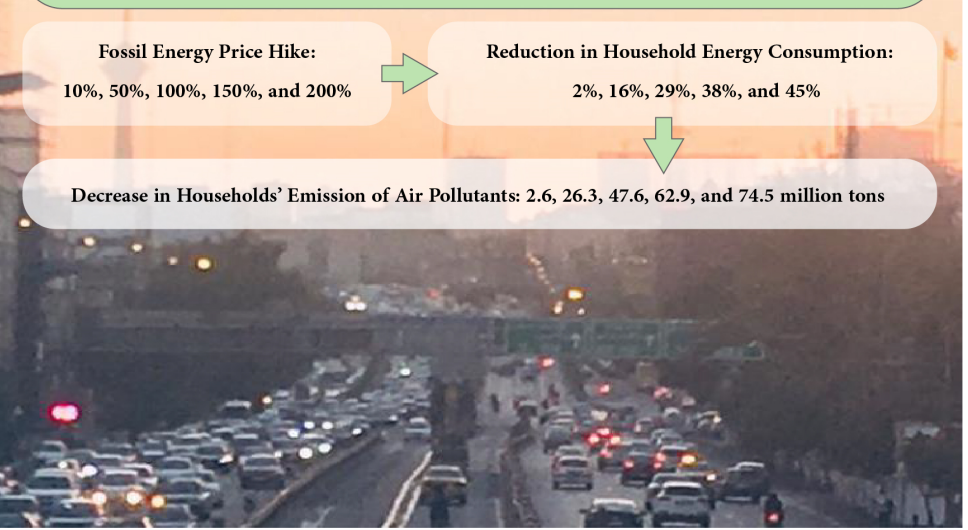

\section{ARTICLE INFO}

\section{Article history:}

Received 5 June 2020

Received in revised form 20 July 2020

Accepted 13 August 2020

Available online 1 September 2020

\section{Keywords:}

Fossil energy

Price subsidy

Energy consumption

Outdoor air pollution

QUAIDS

Iran

\begin{abstract}
Cheap fossil energy leads to overconsumption of energy and hazardous levels of air pollution. In this study, we provide a framework to connect fossil energy price policy to private consumption of energy and outdoor air pollution. We used a consumer demand system and reassessed it for the recent status of the Iranian economy. We extracted household consumption information from Iran's 2011 and 2014-2016 annual household surveys $(n=154683)$, prices from the Central Bank of Iran's detailed monthly price indices from 2008 to 2016, and air pollution information from Iran's Energy Balance Sheets. We estimated that an average Iranian household would reduce its energy consumption by $2 \%, 16 \%, 29 \%, 38 \%$, and $45 \%$ if energy prices were hiked by $10 \%$, $50 \%, 100 \%, 150 \%$, and $200 \%$, respectively. The corresponding reductions in total outdoor air pollution in the post-hike period would be $2.6,26.3,47.6,62.9$, and 74.5 million tons, respectively. Besides highlighting the importance of fossil energy price policy as a short-term strategy to reduce air pollution, this study calls attention to shifting the existing subsidies on fossil fuels to sustainable sources of energy such as waste-oriented biofuels as a -long-term solution.
\end{abstract}

(C) 2020 BRTeam. All rights reserved.

* Corresponding authors at: Tel.: +1 (502) 852-0417

E-mail address: Seyed.Karimi@ louisville.edu 


\section{Contents}

1. Introduction

2. Methodology.

2.1. The QUAIDS model.

2.2. The QUAIDS model for Iran......

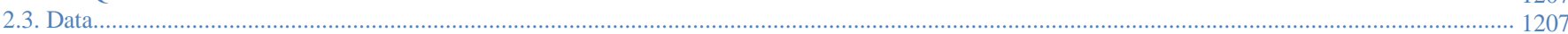

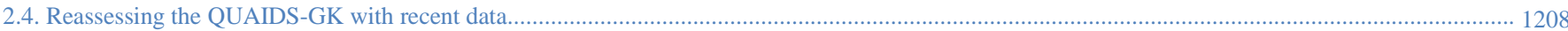

2.4.1. Calculating an updated subsistence level of expenditure

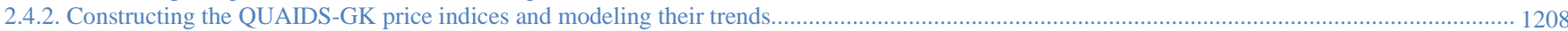

2.4.3. Constructing the QUAIDS-GK expenditures and assessing their trends .................................................................................................... 1208

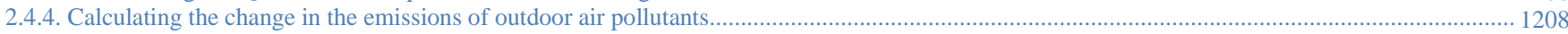

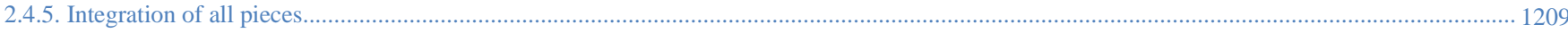

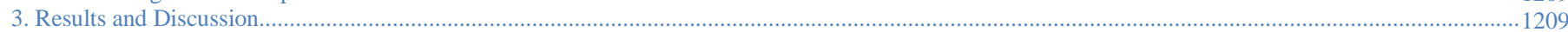

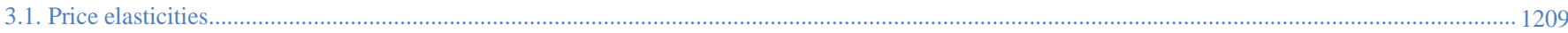

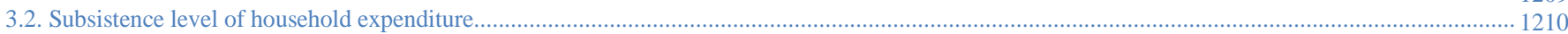

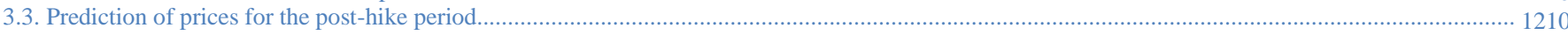

3.4. Prediction of total expenditures and household size for the post-hike period.............................................................................................. 1210

3.5. Predicted changes in energy consumption.

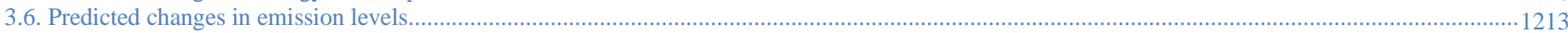

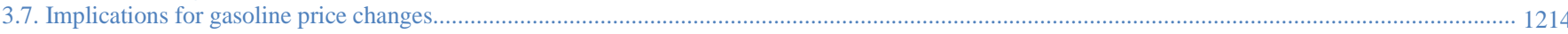

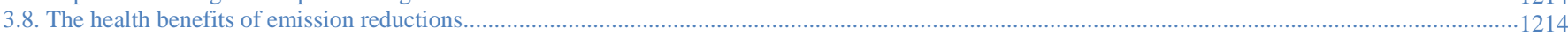

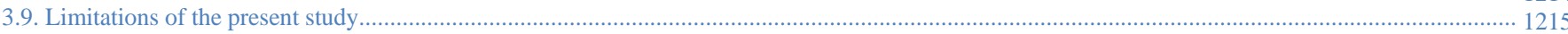

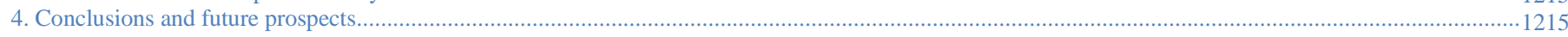

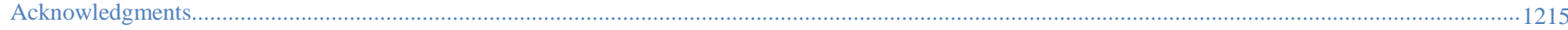

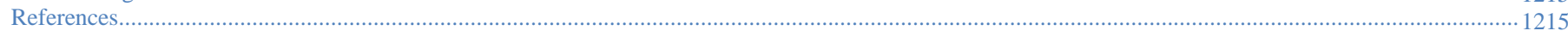

\begin{tabular}{|c|c|}
\hline \multicolumn{2}{|l|}{ Nomenclatures } \\
\hline$a(p)$ and $b(p)$ & Aggregate price indices specified \\
\hline $\mathrm{CH}_{4}$ & Methane \\
\hline $\mathrm{CO}$ & Carbon monoxide \\
\hline $\mathrm{CO}_{2}$ & Carbon dioxide \\
\hline$e_{k l}$ & $\begin{array}{l}\text { The elasticity of (or the percentage change in) the } \\
\text { good } k \text { consumption with respect to a (percentage) } \\
\text { change in the good } l \text { price }\end{array}$ \\
\hline$h$ & A household \\
\hline $\mathrm{N}_{2} \mathrm{O}$ & Nitrous oxide \\
\hline$p$ and $c$ & An air pollutant and an energy carrier \\
\hline$p_{1}, p_{2}, \ldots$, and $p_{G}$ & Price indices of aggregated goods $1,2, \ldots$, and $G$ \\
\hline$q_{k}$ & The quantity of good $k$ consumption \\
\hline Stock $_{p, c}$ & $\begin{array}{l}\text { The stock of air pollutant } p \text { emitted by households, } \\
\text { businesses, and the public sector }\end{array}$ \\
\hline Stock $k_{p, c}^{h}$ & $\begin{array}{l}\text { The stock of air pollutant } p \text { emitted by households' } \\
\text { consumption of energy career } c\end{array}$ \\
\hline Stock $k_{p}^{h}$ & The stock of air pollutant $p$ emitted by households \\
\hline$w_{c}^{h}$ & $\begin{array}{l}\text { The share of the household sector in the total } \\
\text { consumption of the energy career } c\end{array}$ \\
\hline$y$ & Total household expenditures \\
\hline $\begin{array}{l}\alpha_{k}, \gamma_{k 1}, \gamma_{k 2}, \ldots \\
\gamma_{k G}, \beta_{k}, \text { and } \lambda_{k}\end{array}$ & Parameters \\
\hline$\sigma_{k l}$ & The Kronecker delta \\
\hline
\end{tabular}

\section{Introduction}

Price of energy carriers (e.g., gasoline, diesel, natural gas, and electricity) has historically been kept well below their values in the international markets in Iran (Kusch-Brandt, 2019). For example, price of a liter of gasoline was 0.10 US dollars in May 2020 (GPP, 2020), and price of a kilowatt-hour of electricity was 0.01 US dollars in September 2019-both recorded as the second-lowest in the world (GPP, 2019; GPP, 2020).

\begin{tabular}{|ll|}
\hline Abbreviations & \\
AIDS & Almost Ideal Demand System \\
CBI & Central Bank of Iran's \\
COICOP & Central Bank of Iran \\
CO $_{x}$ & Classification of Individual Consumption by \\
CPIs & Carbon oxides \\
EBS & Consumer price indices \\
HEIS & Energy balance sheets \\
HIA & Household Expenditure and Income Survey \\
MoE & Health impact assessment \\
NO & Ministry of Energy's \\
PM10 & Nitrogen oxides \\
PPP & Particulate matter $\leq 10 \mu$ \\
QUAIDS & Parity in purchasing power \\
QUAIDS-GK & Quadratic AIDS \\
SCI & QUAIDS-Gahvari and Karimi \\
SO & Statistical Center of Iran's \\
SPM & Sulfur oxides \\
USD & Suspended particulate matter \\
\hline & US dollars \\
\hline
\end{tabular}

Such low fossil energy prices (or heavy energy price subsidies) have led to several major dilemmas. First, the public has become accustomed to low energy prices, while they are impossible to sustain, as they are often set below the production cost (Coady et al., 2019). Hence, unpopular price hikes have been inevitable. Second, the distribution of energy price subsidies is in favor of the rich. According to an International Monetary Fund estimate, only $3.0 \%$ of the direct benefits of gasoline price subsidies are collected by the bottom income quintile in developing countries; the top income quintile collects $61.3 \%$ of the direct benefits (Del Granado et al. 2012). In Iran, the top income decile's direct benefit from gasoline price subsidies is estimated to be 13.9-fold higher than that for the bottom income 
decile. The ratio was 7.8 and 5.7 for natural gas and electricity price subsidies, respectively (Gahvari and Karimi, 2016). Third, low energy prices have led to inefficient use of energy and elevated levels of outdoor air pollution (Enriquez et al., 2018), such that the air quality in Tehran and other large cities became unhealthy or hazardous in many days of the year in the past decade (Ahadi and Roshani, 2018). The effects of the high levels of air pollution on Iranians' health are well documented (Dehghan et al., 2018, Bayat et al., 2019; Sicard et al., 2019; Karimi et al., 2020). Therefore, if it is gradual and allows for households' and businesses' adjustment and is coupled with an expansion of safety nets, cutting energy price subsidies is redistributive and has public health benefits. More importantly, the retained revenues from eliminating fossil energy price subsidies can be used strategically to fund and incentivize a move toward more sustainable, environmentally-friendly sources of energy (e.g., waste-orientaed biofuels).

Measuring the public health benefits of reduction in outdoor air pollution by cutting energy subsidies, however, is challenging because it requires accounting for households' complementary and substitutionary reactions to price changes. Understanding households' reactions, in turn, requires modeling their preferences and patterns of their consumption. In economic literature, demand systems are developed for this specific purpose. Among the long list of proposed and examined demand systems, the Almost Ideal Demand System (AIDS) is the most popular one because of its desirable theoretical and empirical properties. From the theoretical point of view, it satisfies all axioms of the consumption theory. Also, it is flexible in the sense that it can be considered as the first-order approximation of any other demand systems. Empirically, it perfectly aggregates over households without extra assumption and is relatively simple to estimate using linear estimation methods (Deaton and Muellbauer, 1980a and b). An expansion of the AIDS is the Quadratic AIDS (QUAIDS) that allows for nonlinearity in the relationship between household consumption and income (Bank et al., 1997).

In this study, a QUAIDS model that had been specifically designed and estimated to measure the impacts of a change in energy prices on Iranian households' energy consumption was re-evaluated with the recent data on prices and household consumption. Then, it was used to predict the effects of different scenarios of fossil energy price change on the amount of air pollution emitted by households. As part of a broader health impact assessment (HIA) plan, the predicted changes in air pollution will be used to find the health impacts of a change in energy subsidies. Therefore, this study sits at the intersection of energy and environmental health policies.

\section{Methodology}

\subsection{The QUAIDS model}

The QUAIDS model includes $G$ equations if a household's total expenditures are divided into $G$ mutually exclusive categories. Each equation specifies the share of total expenditures on a category of goods and services as a linear function of the logarithm of all prices and the first and second orders of the price-adjusted total expenditures. The equation for category $k(k \leq G)$ is presented in Equation 1:

$$
\begin{gathered}
\omega_{k}=\alpha_{k}+\gamma_{k 1} \ln p_{1}+ \\
\gamma_{k 2} \ln p_{2}+\ldots+\gamma_{k k} \ln p_{k}+\cdots+\gamma_{k G} \ln p_{G}+\beta_{k} \ln \frac{y}{a(\boldsymbol{p})} \\
+\frac{\lambda_{k}}{b(\boldsymbol{p})}\left[\ln \frac{y}{a(\boldsymbol{p})}\right]^{2}
\end{gathered}
$$

where $\alpha_{k}, \gamma_{k 1}, \gamma_{k 2}, \ldots, \gamma_{k G}, \beta_{k}$, and $\lambda_{k}$ are parameters (Bank et al., 1997). The variables $p_{1}, p_{2}, \ldots$, and $p_{G}$ are price indices of aggregated goods $1,2, \ldots$, and $G$, the variable $y$ is total household expenditures, and variables $a(\boldsymbol{p})$ and $b(\boldsymbol{p})$ are aggregate price indices specified as follows (Eqs. 2 and 3):

$$
a(\boldsymbol{p})=\exp \left(\alpha_{0}+\sum_{k=1}^{G} \alpha_{k} \ln p_{k}+\frac{1}{2} \sum_{k=1}^{G} \sum_{l=1}^{G} \gamma_{k l} \ln p_{k} \ln p_{l}\right)
$$

$b(\boldsymbol{p})=\prod_{k=1}^{G} p_{k}^{\beta_{k}}$

The parameters are constrained to $\sum_{k=1}^{G} \gamma_{k l}=\sum_{l=1}^{G} \gamma_{k l}=0, \sum_{k=1}^{G} \beta_{k}=$ $\sum_{k=1}^{G} \lambda_{k}=0$, and $\sum_{k=1}^{G} \alpha_{k}=1$ to comply with the economic theory of consumption (Bank et al., 1997). Because of the presence of $a(\boldsymbol{p})$ and $b(\boldsymbol{p})$ in the last two terms in the demand equations, they are not linear in parameters. Hence, the equations of the demand system are estimated in more than one step. For example, first, $a(\boldsymbol{p})$ and $b(\boldsymbol{p})$ are computed using an iterating procedure, starting with some initial values for the parameters. Then, the estimated $a(\boldsymbol{p})$ and $b(\boldsymbol{p})$ are used in the final estimation of the parameters using a two-stage least-square method (Gahvari and Karimi, 2016). The estimated demand system is usually used to predict the consumption of the $G$ groups of goods and services and to compute their price elasticities, which can be derived as shown in Equation 4:

$$
\begin{aligned}
& e_{k l}=\frac{\frac{\partial q_{k}}{q_{k}}}{\frac{\partial p_{k}}{p_{k}}}=\frac{1}{\omega_{k}} \frac{\partial \omega_{k}}{\partial \ln p_{l}}-\sigma_{k l} \\
& =\frac{1}{\omega_{k}}\left\{\gamma_{k l}-\left[\beta_{k}+\frac{2 \lambda_{k}}{b(\boldsymbol{p})} \ln \frac{y}{a(\boldsymbol{p})}\right]\left(\alpha_{l}+\sum_{m=1}^{G} \gamma_{l m} \ln p_{m}\right)-\frac{\lambda_{k} \beta_{l}}{b(\boldsymbol{p})}\left[\ln \frac{y}{a(\boldsymbol{p})}\right]^{2}\right\}-\sigma_{k l}
\end{aligned}
$$

where $q_{k}$ denotes the quantity of good $k$ consumption and $\sigma_{k l}$ is the Kronecker delta. Then, $e_{k l}$ is the elasticity of (or the percentage change in) the good $k$ consumption with respect to a (percentage) change in the good $l$ price (Gahvari and Karimi, 2016).

\subsection{The QUAIDS model for Iran}

This study used the estimation of QUAIDS for Iranian households previously described by Gahvari and Karimi (2016). Their mode (QUAIDS-GK henceforth) is particularly suitable for studying Iranian households' responses to energy price changes. First, since the QUAIDSGK was designed to assess the impact of the country's 2011 energy subsidy reform, it used categories of household expenditures that were exclusively constructed in terms of their relation to energy. Specifically, the categories were (1) energy, (2) energy-consuming goods, (3) non-energy-consuming goods, (4) housing, (5) services, (6) subsidized food, and (7) unsubsidized food. Category 1, "energy" includes a household's purchase of all types of fossil energy for consumption purposes: gasoline, electricity, natural gas, liquid gas, kerosene, and diesel. The QUAIDS-GK set aside household spending on other heavily subsidized items such as health and education because their market price cannot be attributed to a typical household's consumption. In addition, it did not include expenditure items for which no price index was available. The QUAIDS-GK also controlled for the household size and the gender of the household head. Second, since the QUAIDS-GK accounted for a long history of Iranian households consumption choices (from 1984 to 2010), it potentially provides an accurate approximation of their preferences.

This study used the QUAIDS-GK parameter estimations but fed it with updated variable values. Hence, it required the use of the recent data on Iranian households' consumption, detailed price indices, and the emission of air pollutants. The information was needed to construct the same expenditure categories used in the QUAIDS-GK, to construct the corresponding categories of price indices, and to find the stock of air pollution generated from households' consumption of energy, respectively. The reassessment of QUAIDS-GK also required recalculating the subsistence level of household expenditures and modeling the trends in household total expenditures and the size and price of non-energy commodity groups.

\subsection{Data}

This study used the data from three different sources: the Statistical Center of Iran's (SCI) household budget surveys, the Central Bank of Iran's (CBI) price indices, and Iran Ministry of Energy's (MoE) energy balance sheets.

Iranian nationally representative household budget surveys, formally known as Household Expenditure and Income Survey (HEIS), have been conducted annually by the SCI since 1968 (SCI, 2020). The HEIS is crosssectional and two-stage stratified. Selecting households randomly and evenly throughout the Persian year (March 21 to March 20 on the Gregorian calendar), the HEIS collects household information in four parts: (1) the household members' sociodemographic characteristics; (2) the household's access to utilities, ownership of major household items such as car and 
home appliances, and dwelling's characteristics; (3) the household's expenditures; and (4) the household members' job and income. The third part, expenditures, is the survey's focus. It contains 1,071 expenditure items categorized according to the United Nations' Classification of Individual Consumption by Purpose (COICOP). The survey's sample size has varied from the smallest (5,760 households) in 1986 to the largest (38,950 households) in 2010. Form 2008, however, the survey has consistently interviewed about 38 thousand households. The electronic version of HEIS data is publicly available from 1984.

The HEIS for three Persian years, 1393-1395 (3/2014 to 2/2017), were used in this study. For the ease of reading, the period was referred to as 2014-2016 in this study. The period included one episode of energy price hike (05/2015), providing an example to study the reaction of the price of other goods to an energy price hike. Data from the more recent HEIS were not used because of the unavailability of detailed price indices in 2017 and 2018.

The Central Bank of Iran (CBI) calculates and publishes all (consumer, producer, wholesale, and exported goods) price indices monthly (CBI, 2020). The consumer price indices (CPIs) are calculated for urban areas where about $72 \%$ of the country's population lives. The CBI also provides aggregated price indices for twelve major commodity groups, but they do not match with the seven commodity groups used in the QUAIDS-GK. Hence, detailed monthly CPIs were used in this study. The detailed data include CPI for 422 specific items and their weights in household's consumption basket. The available price data covered the period of this study and five years before that, namely the Persian years 1387-1395, or 3/2008 to 2/2017 (2008-2016 henceforth, for the ease of reference).

The data on the total amount of air pollutants' emission by economic sectors were extracted from the MoE' energy balance sheets (EBS henceforth). The EBS, annually published from 1987, is a detailed technical report on the production, consumption, and trade of all energy carriers in the country (Energy, 2020). It also provides emission data by energy careers and economics sectors

\subsection{Reassessing the QUAIDS-GK with recent data}

This analysis reassessed the QUAIDS-GK for the recent status of the Iranian economy to predict the impact of a series of energy price hike scenarios on household energy consumption. The considered scenarios were $10 \%, 20 \%, \ldots$, $200 \%$ increases in energy prices. The scenarios represent experiences of energy price hike from 2010 in Iran. The predicted energy consumption changes were used to predict the corresponding changes in air pollutants' levels. The analysis, hence, considered energy consumption and air pollution in two periods: in a pre-energy-price-hike (pre-hike) period and in a hypothetical post-energyprice-hike (post-hike) period. The last year for which all three datasets are available, 2016, was considered as the pre-hike period. Actual values were used to calculate household energy consumption and air pollution in 2016. The next year, 2017, was considered as the post-hike period. Household energy consumption and air pollution in 2017 were predicted.

\subsubsection{Calculating an updated subsistence level of expenditure}

The parameter $\alpha_{0}$ in Equation 2 is interpreted as the minimum subsistence level of household expenditure when all prices are set to one (Deaton and Muellbauer, 1980a and b). By construction, all price indices are equal to one in the base year of CBI price indices. The base year of CBI price indices used in the QUAIDS-GK was 2004 (Gahvari and Karimi, 2016), whereas the base year of the CBI price indices used in this study is 2011 . Hence, this study needed an estimation of the minimum subsistence level of total household expenditures in 2011

The World Bank's most recent recommended poverty line is 1.90 US dollars (USD) per person per day (Ferreira et al., 2015). This dollar value is evaluated in 2011 prices and accounts for parity in purchasing power (PPP) across nations. The poverty line has been applied to Iran as well (Atamanov et al., 2016). Using the World Bank's PPP conversation factor, the private consumption equivalent of one USD was extracted in terms of Iranian currency in 2011 (Bank, 2020). Then, it was multiplied by 1.90 and 365.25 to find an annual per-person poverty line for Iran in 2011. The result was separately multiplied by the average household size in urban areas, rural areas, and the country in 2011 to find household level poverty lines in 2011. The latter numbers were multiplied by $73 \%$, as household's total expenditures in this study were about three-quarters of its actual total expenditures, which include the excluded items such as health care and education services and the items for which no price index was available. The resulted numbers were used as $\alpha_{0}$ in the reassessment of the QUAIDS-GK.

\subsubsection{Constructing the QUAIDS-GK price indices and modeling their trends}

The CBI's 422 monthly CPIs for 2008-2016 were regrouped and weighted into the seven groups of this analysis, in accordance with the groups used in the QUAIDS-GK (each of the 422 item's weight is that item's expenditure share, provided by the CBI). The constructed price indices $\left(p_{k}, k=1,2, \ldots, 7\right)$ were averaged in 2016 and used as the pre-hike price set. They served two purposes. First, alongside the QUAIDS-GK parameter estimates and the updated $\alpha_{0}$, they were fed into Equations 2 and 3 to calculate QUAIDS-GK combined price indices, $a(\boldsymbol{p})$ and $b(\boldsymbol{p})$ Second, alongside the calculated $a(\boldsymbol{p}), b(\boldsymbol{p})$, and other information, they were directly inserted into Equations 1 and 4 to calculate energy consumption and consumption price elasticities in the pre-hike period.

In addition, the six non-energy groups' price indices during the period of this study (2014-2016) were linearly approximated over time. Nonlinear approximations were avoided because they can result in a decrease in prices, which are highly unlikely. Then, the linear approximations were used to predict their price indices in the post-hike period. Next, predicted monthly prices for 2017 were averaged and inserted in Equations 1, 2, and 3 , along with other predicted information, to calculate energy consumption in the post-hike period.

The application of the 2014-2016 trends in the prices of non-energy categories to 2017 assumes that the presumed energy price hikes will not influence the price of non-energy categories. This may be a strong assumption because (1) energy is an input for the production of all other goods, and (2) this study considered substantial increases in the price of energy. The strength of this assumption was investigated by using the 2008 to 2013 price data and assessing the response of the price of non-energy categories to the sharpest increase in the price of energy in recent history-an about $120 \%$ increase in the energy price index in January 2011. The $120 \%$ increase is an average over the percentage increases in all energy careers. For quoted gasoline (up to $60 \mathrm{~L} /$ month), for example, the rate was 300\% (Gahvari and Karimi, 2016).

\subsubsection{Constructing the QUAIDS-GK expenditures and assessing their trends}

The 1,071 expenditure items in the HEIS 2014-2016 were categorized precisely into the seven commodity groups used in the QUAIDS-GK. Next, average household expenditures on the seven commodity groups were calculated separately for urban, rural, and the pooled sample on a quarterly basis in deciles of household income. The expenditures were used in the calculation of total expenditures and expenditure shares. The average household sizes were also calculated. Total expenditures $(y)$ and expenditure shares $\left(\omega_{k}, k=1,2, \ldots, 7\right)$ were averaged in 2016 and, alongside 2016 price indices, were fed into Equation 4 to calculate price elasticities

Also, total expenditures $(y)$ and price indices- $a(\boldsymbol{p}), b(\boldsymbol{p})$, and $p_{k}, k=1$, $2, \ldots, 7$-and household size were averaged in 2016 and inserted in Equation 1 to calculate energy consumption by income decile and urban/rural classification in the pre-hike period. Then, total expenditures and household size during the entire period were fitted with linear trendlines to predict their values in the post-hike period. Next, the predicted total expenditures and household size, alongside the predicted price indices for 2017, were inserted in Equation 1 to calculate energy consumption in the post-hike period. Having energy consumption predicted in both pre- and post-hike periods, a change in energy consumption was calculated under each scenario.

\subsubsection{Calculating the change in the emissions of outdoor air pollutants}

Finally, the predicted changes in households' energy consumption were used to predict changes in households' emission of carbon oxides $\left(\mathrm{CO}_{\mathrm{x}}\right)$, nitrogen oxides $\left(\mathrm{NO}_{\mathrm{x}}\right)$, nitrous oxide $\left(\mathrm{N}_{2} \mathrm{O}\right)$, sulfur oxides $\left(\mathrm{SO}_{\mathrm{x}}\right)$, methane $\left(\mathrm{CH}_{4}\right)$, and suspended particulate matter (SPM). In practice, the predicted 
percentage changes in the consumption of energy were applied to the stocks of household-originated emission of the air pollutants-assuming a linear relationship between energy consumption and emission of the air pollutants.

The stocks of household-originated emissions were calculated using the information provided by EBS 2016. The following formula summarizes the calculation (Eq. 5):

$$
\text { Stock }_{p}^{h}=\sum_{c} \text { Stock }_{p, c}^{h}=\sum_{c} w_{c}^{h} . \text { Stock }_{p, c}
$$

where the superscript $h$ indicates a household, and subscripts $p$ and $c$ indicate an air pollutant and an energy carrier, respectively. The variable Stock ${ }_{p}^{h}$ is the stock of air pollutant $p$ emitted by households. The variable Stock $k_{p, c}^{h}$ is the stock of air pollutant $p$ emitted by households' consumption of energy career $c$. The variable Stock $_{p, c}$ is the stock of air pollutant $p$ emitted by households, businesses, and the public sector. The variable $w_{c}^{h}$ is the share of the household sector in the total consumption of the energy career $c$ by the three sectors.

Equation 5's formulation was dictated by data availability. The EBS reports the total annual consumption of natural gas, liquid gas, kerosene, and diesel for three sectors (namely, household, commerce, and public) separately. The numbers were used to calculate the share of households in the total consumption of each of the four energy carriers (i.e., $w_{\text {natural gas }}^{h}, w_{\text {liquid gas }}^{h}$, $w_{\text {kerosene }}^{h}$, and $\left.w_{\text {diesel }}^{h}\right)$. The EBS does not provide gasoline consumption by the sectors. Hence, households' share of gasoline consumption ( $\left.w_{\text {gasoline }}^{\text {hh }}\right)$ was found from other research (Center, 2019). For each of these energy careers, the EBS also provides the annual emissions of carbon monoxide (CO), carbon dioxide $\left(\mathrm{CO}_{2}\right), \mathrm{NO}_{\mathrm{x}}, \mathrm{N}_{2} \mathrm{O}, \mathrm{SO}_{\mathrm{x}}, \mathrm{CH}_{4}$, and $\mathrm{SPM}$ in tons by household, commerce, and public sectors combined $\left(\right.$ Stock $\left._{p, c}\right)$.

\subsubsection{Integration of all pieces}

Own-price elasticity of energy, calculated for the last year of the period (2016), can be of interest in this study since it provides the percentage change in energy consumption in responses to a percentage change in the price index of energy. While informative, energy own-price elasticity was not used in the prediction of change in the air pollutants' levels under different scenarios of energy price hike for two reasons. First, a price elasticity provides a more accurate prediction of the household's consumption of energy if the energy price change is marginal. Second, it assumes all other factors that influence the household's consumption of energy (especially income and prices of complementary and supplementary goods to energy) remain constant.

Therefore, to assess a realistic condition, the ceteris paribus assumption was relaxed by using predictions of income and other prices for the post-hike period
(2017). In effect, the QUAIDS-GK was utilized twice under each scenario of energy price change: once with 2016 actual information (leading to the calculation of Consumption $_{\text {energy }}^{\text {pre-hike }}$ ) and then with 2017 predicted information (leading to the calculation of Consumption energy $_{\text {post-hike }}^{s}$ where $s=10 \%, 20 \%, \ldots, 200 \%)$. Thus, the change in the consumption of energy under each scenario was calculated as presented in Equation 6:

$$
\begin{aligned}
& \begin{array}{l}
\Delta \text { Consumption } \\
\text { energy }
\end{array}=\text { Consumption } \\
& \text { Consumption } \\
& \text { pre-hike }
\end{aligned}
$$

Using predicted changes from Equation 6, changes in energy consumption as the percentage of the pre-hike period levels were

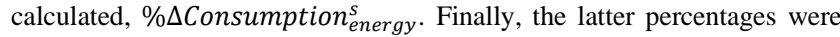
applied to the stocks of air pollutants in 2016 (Eq. 5) to calculate the percentage change in air pollution levels as follows (Eq. 7):

$$
\% \Delta \text { Stock } k_{p}^{h^{s}}=\% \Delta \text { Consumption } \text { energy }^{s} \times \text { Stock }_{p}^{h}
$$

Figure 1 illustrates the entire calculation procedure. The procedure was repeated for each scenario separately for urban areas, rural areas, and the country.

\section{Results and Discussion}

\subsection{Price elasticities}

The energy consumption's own-price elasticity was -0.63 in 2016 for an average Iranian household. In other words, a marginal $1 \%$ increase in energy prices would decrease an average Iranian household's consumption of energy by $0.63 \%$, assuming no change in other prices and income. Across deciles of income, the energy own-price elasticity varied from -0.67 to -0.47 such that it decreased in absolute value as income increased. Less than one elasticity indicates that energy consumption is inelastic to its price across all income groups (Table 1). The estimated range of energy price elasticity for Iran is in the range of what is estimated for other countries. For example, a meta-analysis of 1010 price elasticities of energy demand estimated for different countries reported mean and median elasticities of 0.43 and -0.60 , respectively (Labandeira et al. 2017).

At any income decile, an urban household was less sensitive to an energy price change than a rural household. In rural and urban areas, the energy price elasticity ranged from -0.70 to -0.59 and from -0.62 to -0.38 , respectively. In both urban and rural areas, the own-price elasticity of energy only slightly varied by income for the lower half of the income distribution. However, it continuously decreased by income for the upper

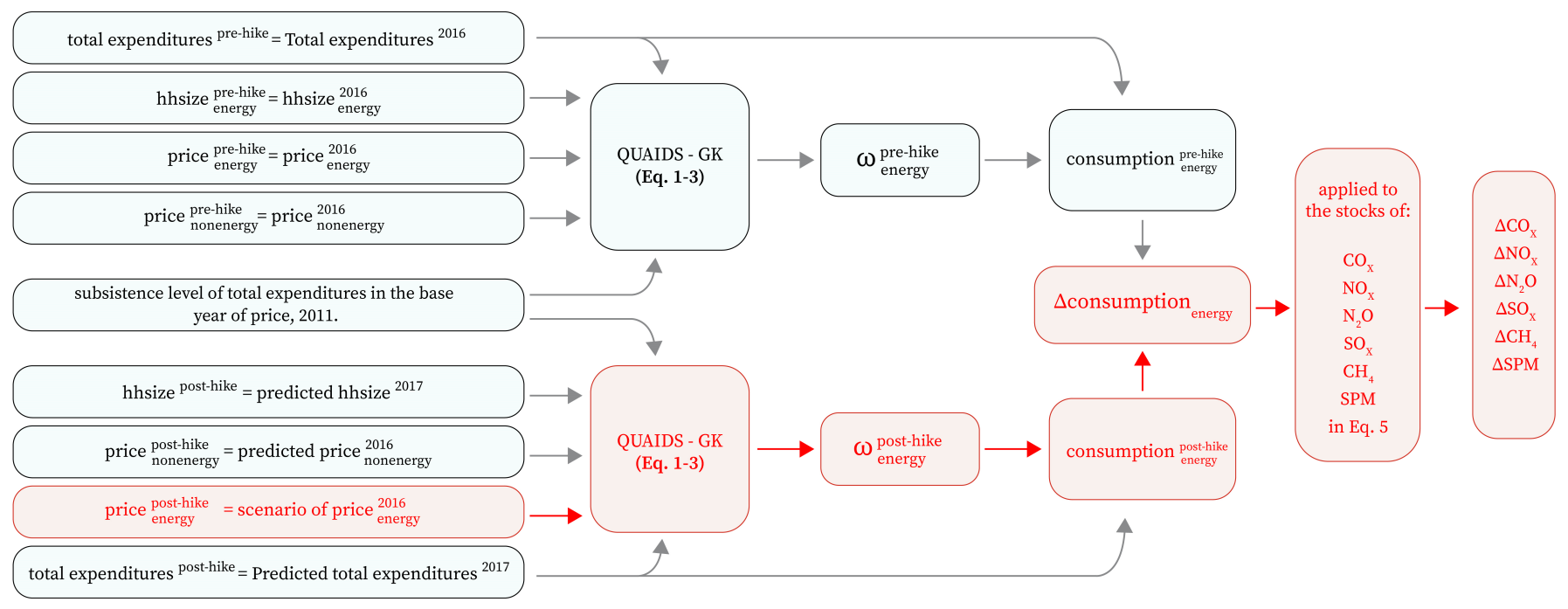

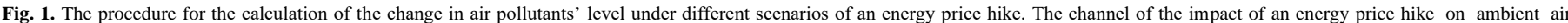
pollutant levels is red-highlighted. 
Table 1.

Main Own-price elasticity of energy in 2016

\begin{tabular}{lccc}
\hline \multirow{2}{*}{ Income decile } & Pooled & Urban & Rural \\
\cline { 2 - 4 } & $\mathbf{n = 3 8 1 4 6}$ & $\mathbf{n = 1 8 8 0 9}$ & $\mathbf{n = 1 9 3 3 7}$ \\
\hline 1 & -0.67 & -0.62 & -0.68 \\
2 & -0.67 & -0.61 & -0.70 \\
3 & -0.65 & -0.61 & -0.69 \\
4 & -0.64 & -0.61 & -0.68 \\
5 & -0.66 & -0.60 & -0.67 \\
6 & -0.64 & -0.60 & -0.68 \\
7 & -0.63 & -0.59 & -0.68 \\
8 & -0.61 & -0.58 & -0.67 \\
9 & -0.59 & -0.55 & -0.65 \\
10 & -0.47 & -0.38 & -0.58 \\
Average & -0.63 & -0.58 & -0.67 \\
\hline
\end{tabular}

half of the income distribution. Households in the top income decile, however, were far less sensitive to an energy price change (Table 1 ).

Among the six non-energy categories of goods and services, energyconsuming goods were the most sensitive to an energy price change. An average-income household would decrease its consumption of energyconsuming goods by $0.46 \%$ in response to a $1 \%$ increase in the price energy (Table 2, column 1). The sensitivity of consumption of energy-consuming goods to energy price was strongly correlated with income such that a bottom, mid-, and top-income decile household would decrease its consumption of the goods by $3.74 \%, 0.86 \%$, and $0.10 \%$ in response to a $1 \%$ increase in the price energy, respectively (Supplementary file; Table S1).

\subsection{Prediction of prices for the post-hike period}

Figure 2 illustrates the monthly price indices of the seven categories of goods and services in this study. The government controls the price of major energy careers. Hence, the energy price index is not affected by market forces and changes only when it is externally updated. The period contains two cases of energy price hikes, one in April 2014 by $17 \%$ and the other in June 2015 by $11 \%$, neither resulted in a significant change in the trend of other price indices. This study, however, considers much higher increases (up to 200\%) in the price of energy. One may suspect if the price indices of non-energy consumption items will be significantly affected by a doubling or tripling of the price of energy careers. Thus, any prediction of their price must account for the effect. The past experience, nevertheless, does not confirm the suspension. Specifically, when the energy price index jumped by about $120 \%$ in the first month of 2011 because of the implementation of the 2011 energy subsidy reform (Gahvari and Karimi, 2016), price indices of non-energy categories did not follow the jump (Supplementary file; Fig. S1). They started a fast-paced increasing trend in 2012, well after the subsidy reform, for another reason (the country faced international financial sanctions) (Haidar, 2020).

Given the observations from Figure 2 and Figure S1 (Supplementary file), the 2017 non-energy prices were predicted based on their trends in 2014-2016. The linear trendlines, which largely explain a substantial portion of the variations in the price indices (represented by R-squared in Fig. 2), were used for the prediction of monthly price indices in 2017.

\subsection{Prediction of total expenditures and household size for the post-hike period}

Real (inflation-adjusted) household total expenditure-the sum of expenditures on the seven categories of goods and services-was stable during the period (Fig. 3). If household income does not change because of, for example, a rebate to households to compensate for the welfare effects of an energy price hike or an improvement in workers' productivity, then it

Table 2.

Cross-price elasticities for an average-income household in 2016

\begin{tabular}{|c|c|c|c|c|c|c|c|c|}
\hline & & \multicolumn{7}{|c|}{ Price Change in: } \\
\hline & & Energy & $\begin{array}{c}\text { Energy- consuming } \\
\text { good } \\
\end{array}$ & $\begin{array}{c}\text { Non-energy- consuming } \\
\text { good }\end{array}$ & Services & Housing & $\begin{array}{c}\text { Subsidized } \\
\text { food }\end{array}$ & $\begin{array}{c}\text { Unsubsidized } \\
\text { food }\end{array}$ \\
\hline \multirow{7}{*}{$\begin{array}{l}\text { Consumption } \\
\text { change in: } \rightarrow\end{array}$} & Energy & -0.63 & -0.12 & -0.10 & -0.02 & 0.01 & 0.13 & -0.22 \\
\hline & Energy-consuming good & -0.46 & -1.10 & -0.45 & -0.46 & -0.29 & 0.09 & 0.25 \\
\hline & Energy-consuming good & -0.10 & -0.08 & -0.34 & -0.21 & -0.11 & -0.27 & -0.19 \\
\hline & Services & -0.03 & -0.09 & -0.19 & -0.64 & -0.18 & 0.04 & -0.11 \\
\hline & Housing & 0.00 & 0.02 & 0.00 & -0.06 & -0.90 & -0.11 & 0.05 \\
\hline & Subsidized food & 0.12 & 0.05 & -0.20 & 0.09 & -0.10 & -0.69 & 0.10 \\
\hline & Unsubsidized food & -0.07 & 0.09 & -0.02 & -0.01 & 0.11 & 0.00 & -0.92 \\
\hline
\end{tabular}

\subsection{Subsistence level of household expenditure}

Considering parity in purchasing power, one USD was equivalent to 5001 Iranian tomans in 2011, the base year of the CBI price indices (Bank, 2020). By the World Bank standards, the poverty line in the year was 9502 $(=5001 \times 1.90)$ tomans for a person in a day (Ferreira et al., 2015). For the year, it was $3470821(=9502 \times 365.25)$ tomans for a person. The size of a poor Iranian household in 2011 was 2.14 ; hence, the poverty line was 7288724 $(=3422028 \times 2.14)$ tomans in 2011 . As the total expenditures in this study constituted about $73 \%$ of actual total expenditures, the annual household-level poverty line relevant to this study was $5406205(=7288724 \times 0.7283)$ tomans. The latter number was used as the subsistence level total expenditures, $\alpha_{0}$, in this study (Deaton and Muellbauer, 1980a and b). When urban and rural households were considered, $\alpha_{0}$ was adjusted accordingly. is reasonable to expect that the pattern of real total household expenditures would not change drastically. Instead, it would increase with a small slope, modeled by a linear trendline. Accordingly, urban and rural household expenditures by deciles of income were modeled and projected for 2017.

The size of Iranian households had a slightly decreasing trend during the period (Fig. 4). Since it is not expected that the household size in any income group notably changes during a year or respond to energy prices in the short-term, the 2016 household sizes in urban and rural areas and for different income deciles were used for 2017.

\subsection{Predicted changes in energy consumption}

The updated subsistence levels of expenditure and predicted non-energy prices, total household expenditures, and household sizes were plugged into 


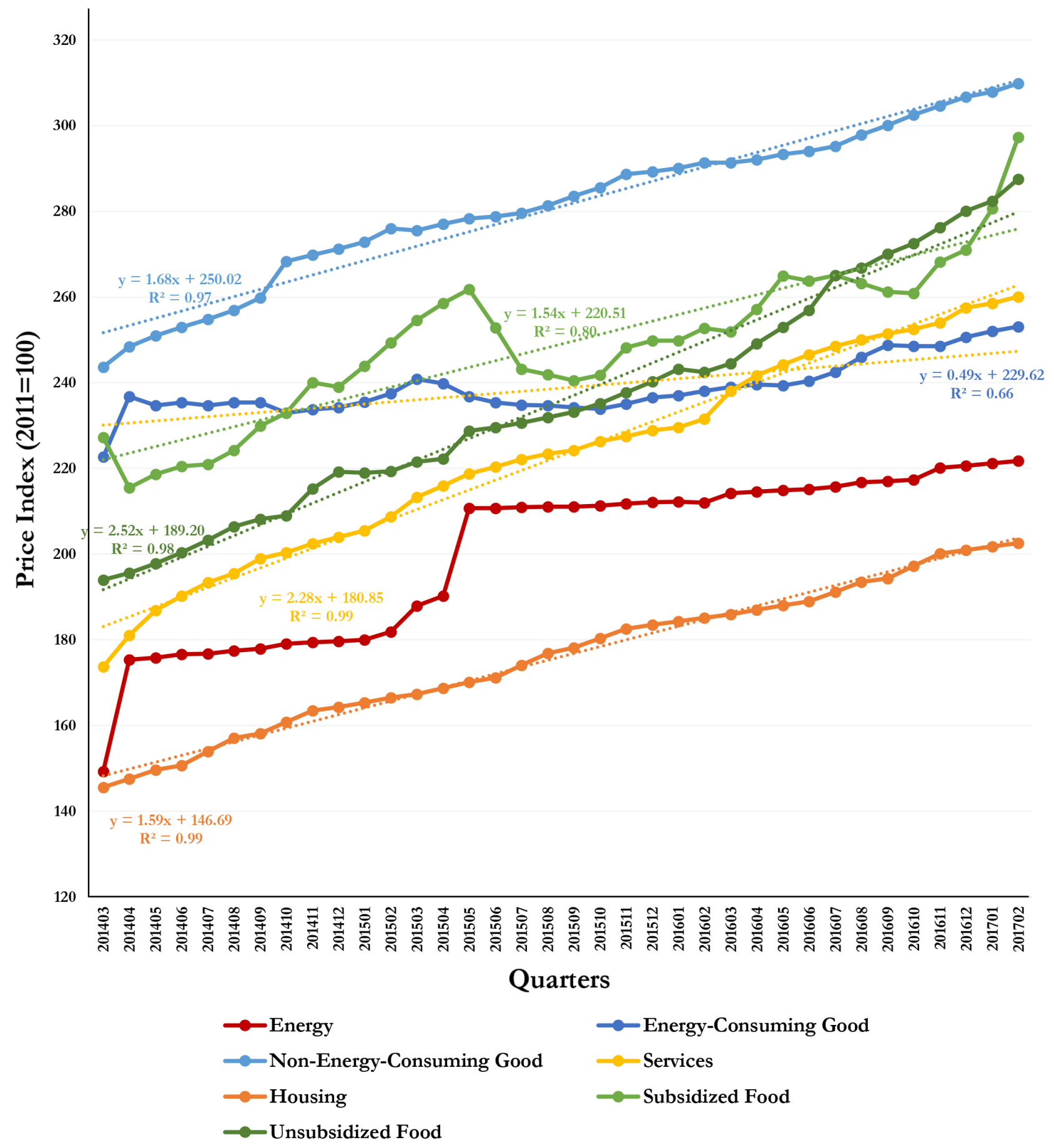

Fig. 2. Price indices of the seven categories of goods and services with their fitted trendlines during the period of this study (2011=100).

Equation 1 to predict toman-denominated measures of energy consumption in 2017 under different scenarios of energy price hike, Consumption post-hike ${ }^{s}$ with $s=10 \%, 20 \%, \ldots, 200 \%$. Also, the toman-denominated measures of energy consumption in the pre-hike period, Consumption energy $_{\text {pre-hike }}$, were calculated by plugging 2016 values into Equation 1. Plugging the pre- and post-hike consumption values in Equation 6, the change in the consumption of energy under each scenario was calculated.
Table 3 presents the change as the percentage of the pre-hike period consumption level for the pooled sample. The results show that a $10 \%$ increase in energy carriers' prices will result in a $2 \%$ decrease in energy consumption for the average household. Greater increases in energy carriers' prices will lead to greater reductions in energy consumption. For example, $50 \%, 100 \%, 150 \%$, and $200 \%$ increases in energy price index will lead to $16 \%, 29 \%, 38 \%$, and $45 \%$ decreases in energy consumption, 


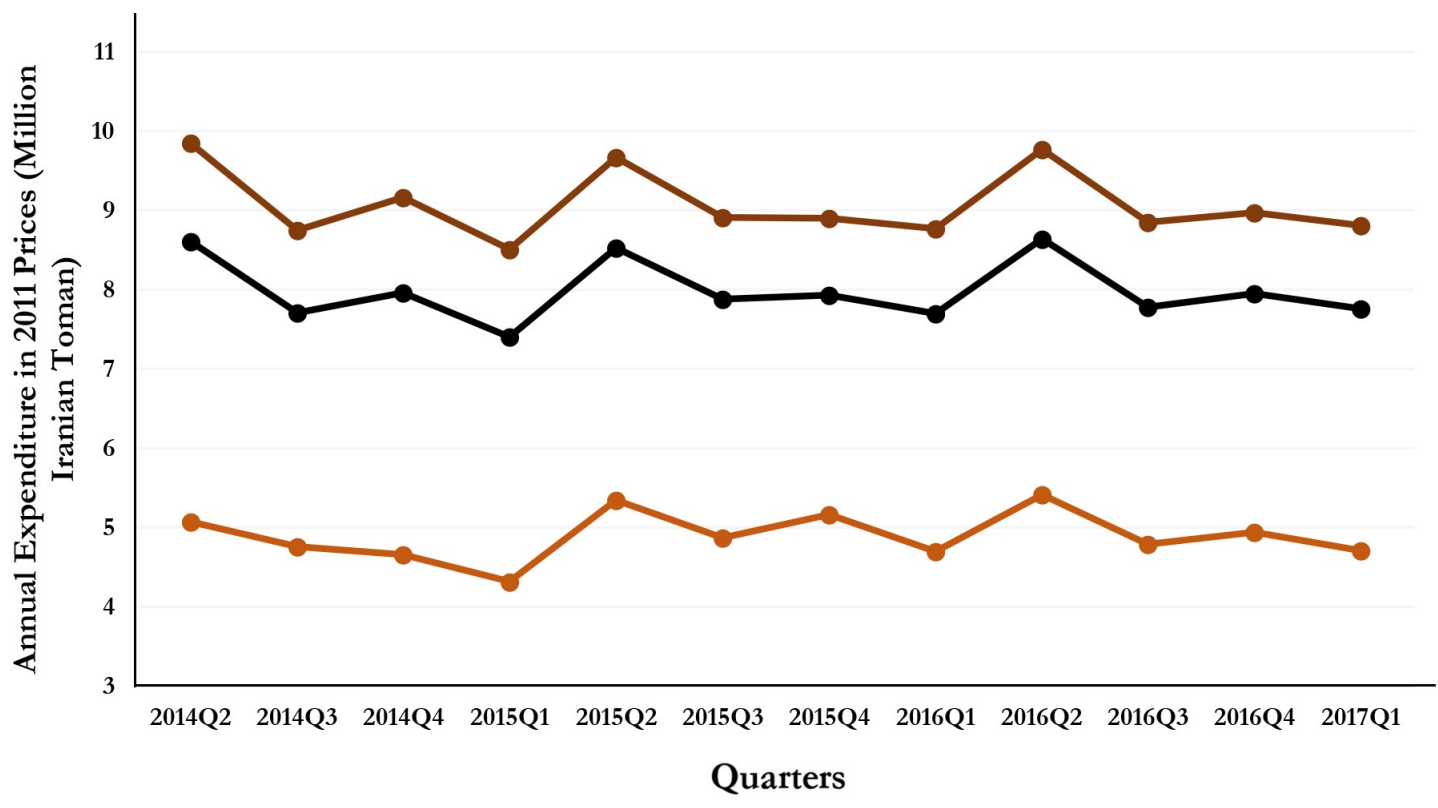

$\rightarrow$ Pooled $\longrightarrow$ Urban $\longrightarrow$ Rural

Fig. 3. An average Iranian household annual expenditure on the seven categories of goods and services in 2011 prices by surveying quarter (numbers in million Iranian Toman).

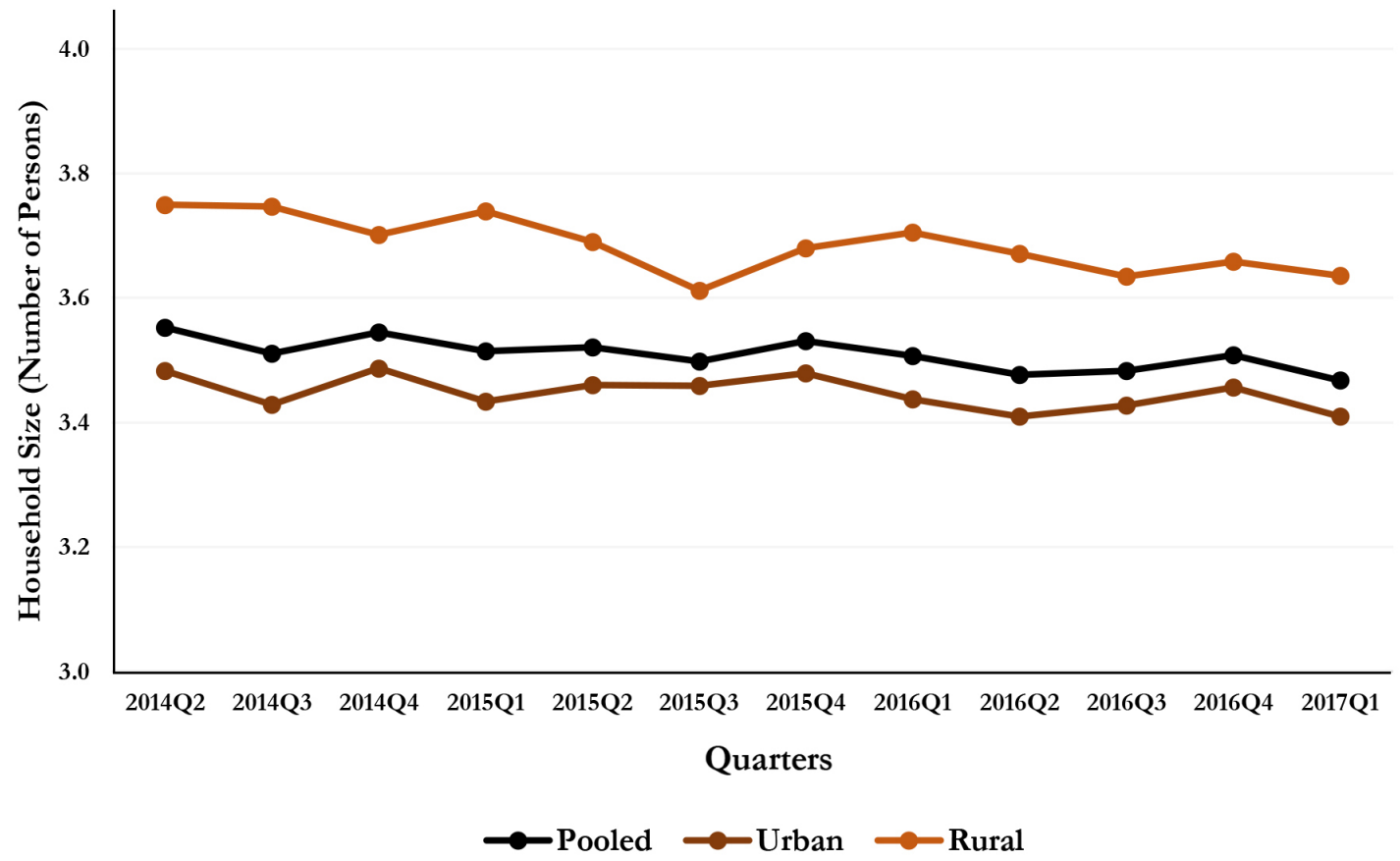

Fig. 4. The size of an average household during the period of this study by surveying quarter.

respectively, for the average household. Under any of the scenarios, the variation in the measured consumption changes is small (up to 4\%) across income deciles. Figure 5 illustrates the patterns of the percentage change in energy consumption under different energy price hike scenarios for the top and bottom income deciles. Urban- and rural-specific calculations, presented in Table S2 (Supplementary file) do not show much difference from those tabulated in Table 3.
This study's estimated change in energy consumption differed from what was estimated by Gahvari and Karimi (2016), who applied the same QUAIDS model to Iran's $120 \%$ energy price hike in 2011. They estimated a $24 \%$ decrease in fossil energy consumption for an average Iranian household. This analysis estimated a 33\% decrease in the average Iranian household's fossil energy consumption for the same percentage increase in energy prices. The reason for the difference is that the 2011 energy price 
Table 3.

Percentage change in energy consumption by income decile under different scenarios of energy price hike (the pooled sample).

\begin{tabular}{|c|c|c|c|c|c|c|c|c|c|c|c|c|c|c|c|c|c|c|c|c|}
\hline \multirow{2}{*}{$\begin{array}{l}\text { Income } \\
\text { decile }\end{array}$} & \multicolumn{20}{|c|}{ The presumed increase in the energy price index in $\%: \downarrow$} \\
\hline & 10 & 20 & 30 & 40 & 50 & 60 & 70 & 80 & 90 & 100 & 110 & 120 & 130 & 140 & 150 & 160 & 170 & 180 & 190 & 200 \\
\hline 1 & 3 & -1 & -5 & -9 & -12 & -15 & -18 & -21 & -23 & -25 & -27 & -29 & -31 & -33 & -35 & -36 & -38 & -39 & -41 & -42 \\
\hline 2 & 1 & -3 & -7 & -11 & -14 & -17 & -20 & -22 & -25 & -27 & -29 & -3 & -33 & -35 & -36 & -38 & -39 & -41 & -42 & -43 \\
\hline 3 & 1 & -3 & -7 & -11 & -14 & -17 & -20 & -22 & -25 & -27 & -29 & -31 & -33 & -35 & -37 & -38 & -40 & -41 & -42 & -44 \\
\hline 4 & 0 & -4 & -8 & -11 & -14 & -17 & -20 & -23 & -25 & -27 & -29 & -31 & -33 & -35 & -37 & -38 & -40 & -41 & -42 & -44 \\
\hline 5 & -1 & -5 & -8 & -12 & -15 & -18 & -21 & -23 & -26 & -28 & -30 & -32 & -34 & -36 & -37 & -39 & -40 & -42 & -43 & -44 \\
\hline 6 & -1 & -5 & -9 & -12 & -16 & -19 & -21 & -24 & -26 & -28 & -30 & -32 & -34 & -36 & -38 & -39 & -41 & -42 & -43 & -44 \\
\hline 7 & -2 & -6 & -9 & -13 & -16 & -19 & -22 & -24 & -27 & -29 & -31 & -33 & -35 & -36 & -38 & -39 & -41 & -42 & -44 & -45 \\
\hline 8 & -2 & -6 & -10 & -14 & -17 & -20 & -22 & -25 & -27 & -29 & -31 & -33 & -35 & -37 & -38 & -40 & -41 & -43 & -44 & -45 \\
\hline 9 & -3 & -7 & -11 & -14 & -17 & -20 & -23 & -25 & -27 & -29 & -31 & -33 & -35 & -37 & -38 & -40 & -41 & -43 & -44 & -45 \\
\hline 10 & -2 & -6 & -9 & -13 & -16 & -19 & -21 & -24 & -26 & -28 & -30 & -32 & -34 & -35 & -37 & -38 & -40 & -41 & -43 & -44 \\
\hline Average household & -2 & -6 & -9 & -13 & -16 & -19 & -22 & -24 & -27 & -29 & -31 & -33 & -35 & -36 & -38 & -39 & -41 & -42 & -43 & -45 \\
\hline
\end{tabular}

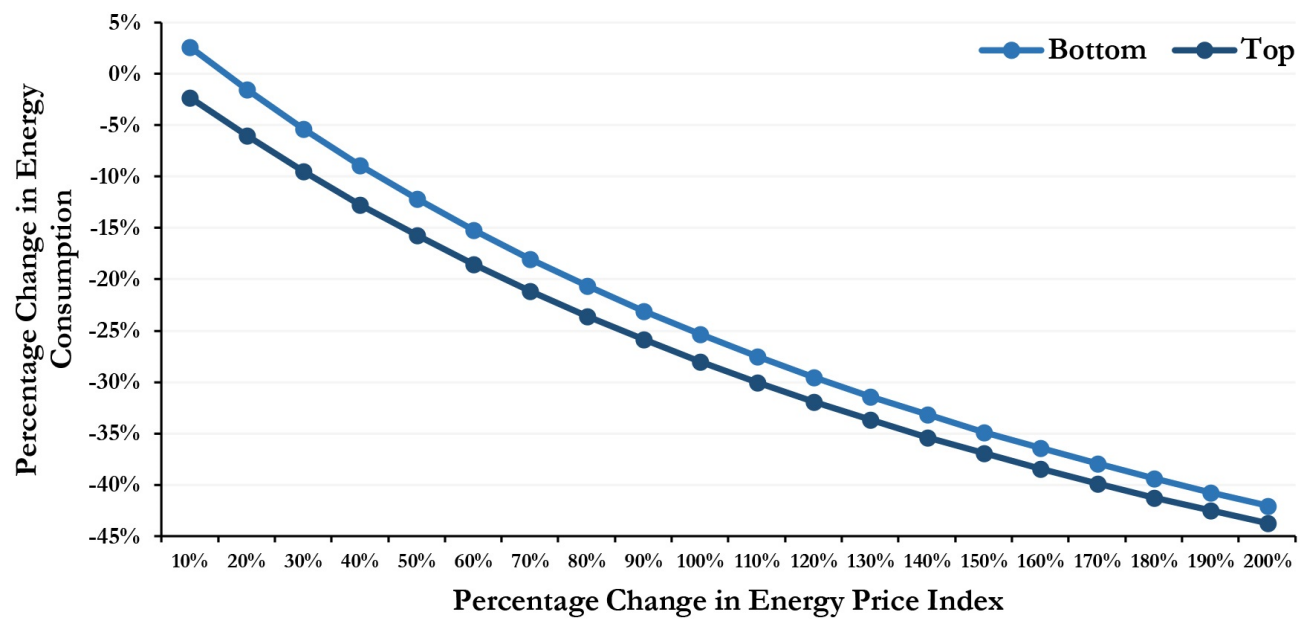

Fig. 5. Percentage change in energy consumption for the top and bottom income deciles under different scenarios of energy price hike (the pooled sample).

hike was part of an energy subsidy reform that included a direct per-person rebate to households to compensate for their welfare losses due to the sharp increase in energy prices. Therefore, the income effect of the rebate limited the expected decrease in energy prices. As an example from another country, it was predicted that gasoline consumption would decrease by 53\% in Saudi Arabia if its price were hiked to the global spot market price, an approximately $256 \%$ increase (Davis, 2017).

The sensitivity of energy consumption to its price, reflected in both the ownprice elasticity of energy (Table 1) and the predicted consumption change (Table 3), is expectedly greater among the lower-income and rural households. The major reason is that the rate of the ownership of major energy-consuming goods is noticeably lower among them. For example, in 2016, 48\% of urban households owned a car, while the rate was only $27 \%$ for rural households. In both urban and rural areas, the rate of car ownership almost monotonically increased by income such that it was $6 \%(<1 \%), 16 \%(6 \%), 29 \%(10 \%), 36 \%$ (15\%), $44 \%(26 \%), 50 \%(37 \%), 58 \%(48 \%), 69 \%(57 \%), 78 \%(66 \%)$, and $87 \%$ (71\%) in the first to tenth urban (rural) income deciles, respectively (SCI, 2020). Also, expectedly, consumption of energy-consuming goods is most sensitive to energy prices since they are complementary goods to energy. The sensitivity is greater among lower-income households, again, as expected. Therefore, after an energy price hike, lower-income households would be in a greater need for public services (e.g., public transportation) and aids than higher-income households (Table 2).
Comparing the predicted changes in energy consumption with the ownprice energy elasticities shows the importance of accounting for anticipated changes in non-energy prices and income. Own-price elasticities are relatively large as they assume no change in other prices and income (presented in Table 1). However, if changes in other prices and income (income changes because of both the trend in real income and inflation adjustment) are accounted, predicted percentage changes in consumption are much smaller, especially for under $50 \%$ scenarios. The predicted consumption changes approach to what is predicted by elasticities only when very large energy price hikes are considered.

\subsection{Predicted changes in emission levels}

The predicted percentage changes in average households' consumption of energy were applied to the calculated stock of outdoor air pollutants emitted by households (presented in Table 4) to find the change in the amount of the air pollutants in the post-hike year. The results show that a $50 \%$ increase in energy carriers' prices (associated with a $16 \%$ decrease in energy consumption), can lead to $910130,25381389,50874,324,5301$, 3274 , and 4852 tons decreases in $\mathrm{CO}, \mathrm{CO}_{2}, \mathrm{NO}_{\mathrm{x}}, \mathrm{N}_{2} \mathrm{O}, \mathrm{SO}_{\mathrm{x}}, \mathrm{CH}_{4}$, and $\mathrm{PM} 10$ levels, respectively. For a $100 \%$ increase in energy carriers' prices (associated with a $29 \%$ decrease in energy consumption), the measured decreases in air pollutants levels are $1628587,45871104,91944,585,9580$ 
Table 4.

The stock of air pollutants created by households' consumption of energy in 2016 (numbers in tons).

\begin{tabular}{lccccccc}
\hline & CO & $\mathbf{C O}_{2}$ & NOx & N$_{2} \mathbf{O}$ & SOx & CH4 & SPM \\
\hline Gasoline & 5726761 & 38927491 & 220889 & 1798 & 24543 & 18537 & 21271 \\
Diesel & 2314 & 7726560 & 1484 & 64 & 7121 & 322 & 0 \\
Natural gas & 22 & 313218 & 556 & 3 & 1768 & 13 & 111 \\
LNG & 13726 & 6301369 & 1372 & 10 & 30 & 100 & 0 \\
Kerosene & 13491 & 108864827 & 100678 & 194 & 402 & 2041 & 9615 \\
Total & 5756314 & 162133465 & 324980 & 2068 & 33864 & 20912 \\
\hline
\end{tabular}

Table 5 .

Predicted decrease in total emission of air pollutants by source under four scenarios of energy price hike (numbers in tons).

\begin{tabular}{|c|c|c|c|c|c|c|c|}
\hline & $\mathrm{CO}$ & $\mathrm{CO}_{2}$ & $\mathbf{N O}_{\mathbf{x}}$ & $\mathbf{N}_{2} \mathrm{O}$ & SO $_{\mathbf{x}}$ & $\mathrm{CH}_{4}$ & SPM \\
\hline \multicolumn{8}{|c|}{$\mathbf{5 0 \%}$ Increase in energy price } \\
\hline $\begin{array}{l}\text { Gasoline } \\
\text { Diesel } \\
\text { Natural gas } \\
\text { LNG } \\
\text { Kerosene } \\
\text { Total }\end{array}$ & $\begin{array}{c}-896503 \\
-3 \\
-2112 \\
-2149 \\
-362 \\
-901130\end{array}$ & $\begin{array}{c}-6093954 \\
-49033 \\
-17042383 \\
-986456 \\
-1209564 \\
-25381389\end{array}$ & $\begin{array}{c}-34579 \\
-87 \\
-15761 \\
-215 \\
-232 \\
-50874\end{array}$ & $\begin{array}{c}-281 \\
0 \\
-30 \\
-2 \\
-10 \\
-324\end{array}$ & $\begin{array}{c}-3842 \\
-277 \\
-63 \\
-5 \\
-1115 \\
-5301\end{array}$ & $\begin{array}{c}-2902 \\
-2 \\
-304 \\
-16 \\
-50 \\
-3274\end{array}$ & $\begin{array}{c}-3330 \\
-17 \\
-1505 \\
0 \\
0 \\
-4852\end{array}$ \\
\hline \multicolumn{8}{|c|}{$100 \%$ Increase in energy price } \\
\hline $\begin{array}{l}\text { Gasoline } \\
\text { Diesel } \\
\text { Natural gas } \\
\text { LNG } \\
\text { Kerosene } \\
\text { Total }\end{array}$ & $\begin{array}{c}-1620226 \\
-6 \\
-3817 \\
-3883 \\
-655 \\
-1628587\end{array}$ & $\begin{array}{c}-11013439 \\
-88616 \\
-30800241 \\
-1782795 \\
-2186013 \\
-45871104\end{array}$ & $\begin{array}{c}-62494 \\
-157 \\
-28484 \\
-388 \\
-420 \\
-91944\end{array}$ & $\begin{array}{c}-509 \\
-1 \\
-55 \\
-3 \\
-18 \\
-585\end{array}$ & $\begin{array}{c}-6944 \\
-500 \\
-114 \\
-8 \\
-2015 \\
-9581\end{array}$ & $\begin{array}{c}-5245 \\
-4 \\
-549 \\
-28 \\
-91 \\
-5917\end{array}$ & $\begin{array}{c}-6018 \\
-31 \\
-2720 \\
0 \\
0 \\
-8770\end{array}$ \\
\hline \multicolumn{8}{|c|}{$150 \%$ Increase in energy price } \\
\hline $\begin{array}{l}\text { Gasoline } \\
\text { Diesel } \\
\text { Natural gas } \\
\text { LNG } \\
\text { Kerosene } \\
\text { Total }\end{array}$ & $\begin{array}{c}-2141183 \\
-8 \\
-5044 \\
-5132 \\
-865 \\
-2152232\end{array}$ & $\begin{array}{c}-14554626 \\
-117109 \\
-40703544 \\
-2356023 \\
-2888889 \\
-60620192\end{array}$ & $\begin{array}{c}-82588 \\
-208 \\
-37643 \\
-513 \\
-555 \\
-121507\end{array}$ & $\begin{array}{c}-672 \\
-1 \\
-72 \\
-4 \\
-24 \\
-773\end{array}$ & $\begin{array}{c}-9176 \\
-661 \\
-150 \\
-11 \\
-2663 \\
-12661\end{array}$ & $\begin{array}{c}-6931 \\
-5 \\
-726 \\
-37 \\
-120 \\
-7819\end{array}$ & $\begin{array}{c}-7953 \\
-42 \\
-3595 \\
0 \\
0 \\
-11589\end{array}$ \\
\hline \multicolumn{8}{|c|}{$200 \%$ Increase in energy price } \\
\hline $\begin{array}{l}\text { Gasoline } \\
\text { Diesel } \\
\text { Natural gas } \\
\text { LNG } \\
\text { Kerosene } \\
\text { Total }\end{array}$ & $\begin{array}{c}-2534224 \\
-10 \\
-5970 \\
-6074 \\
-1024 \\
-2547301\end{array}$ & $\begin{array}{c}-17226311 \\
-138606 \\
-48175191 \\
-2788501 \\
-3419181 \\
-71747789\end{array}$ & $\begin{array}{c}-97749 \\
-246 \\
-44552 \\
-607 \\
-657 \\
-143811\end{array}$ & $\begin{array}{c}-795 \\
-1 \\
-86 \\
-4 \\
-28 \\
-915\end{array}$ & $\begin{array}{c}-10861 \\
-782 \\
-178 \\
-13 \\
-3151 \\
-14985\end{array}$ & $\begin{array}{c}-8203 \\
-6 \\
-859 \\
-44 \\
-143 \\
-9254\end{array}$ & $\begin{array}{c}-9413 \\
-49 \\
-4255 \\
0 \\
0 \\
-13717\end{array}$ \\
\hline
\end{tabular}

5917, and 8770 tons for $\mathrm{CO}, \mathrm{CO}_{2}, \mathrm{NO}_{x}, \mathrm{~N}_{2} \mathrm{O}, \mathrm{SO}_{x}, \mathrm{CH}_{4}$, and particulate matter $\leq 10 \mu$ (PM10), respectively. Table 5 presents the reduction in the air pollutants' levels for two other scenarios, $150 \%$ and $200 \%$, as well. Table S3 (Supplementary file) provides the predicted reductions for all scenarios.

\subsection{Implications for gasoline price changes}

By construction, the scenarios of energy price change in this study apply to all types of energy that a household consumes. In other words, a presumed $100 \%$ hike in energy price assumes a $100 \%$ price hike in the full list of energy items that a household consumed, namely, electricity, natural gas, liquid gas, kerosene, diesel, and gasoline. The latter is used for transportation purposes by households; the others are for residential uses. Whereas an overall energy price hike was implemented by the 2011 energy subsidy reform, the most recent energy price hike (a 200\% increase) was limited to gasoline (Fassihi, 2019). Hence, the question is what the implications of the results of this study are for the most recent experience.

Gasoline constituted approximately $40 \%$ of all energy expenditures of an average urban Iranian household in 2014-2016. Assuming that gasoline is not substitutable with other energy carriers (a reasonable assumption in the shortrun), changes in gasoline consumption would be equal to the predicted changes in energy consumption. Hence, the predicted changes in the emission of air pollutants would come merely from gasoline-related emissions, reported in the first row of each panel in Table 5 and Table S3 (Supplementary file).

\subsection{The health benefits of emission reductions}

The adverse effect of air pollution on human health is vastly investigated. It causes death and disability mainly through increasing the risk of respiratory and cardiovascular diseases and cancer (Guarnieri anc Balmes, 2014; Sørensen et al., 2014; Cai et al., 2016; Turner et al., 2017; Roth et al., 2018). The negative impacts of air pollution on Iranians' health have also been well-studied (Dehghan et al., 2018; Bayat et al., 2019; Sicard et al., 2019; Karimi et al., 2020).

Investigating the public health gains from the reduced levels of air pollution, induced by an energy price hike, requires a separate analysis. Such a study will connect energy policy to environmental health policy. Nonetheless, the results from a recent study can be combined with the results from this study to provide some rough estimates for the extent of the potential health gains of an energy price hike. That study showed that a $25 \%$ persistent decrease in CO level is associated with about 2700 (in 100000 ) fewer cases of reporting chronic diseases (including cancer, stroke and myocardial infarction, asthma, hypertension, and diabetes) among the 60-plus-year-old Tehranis (Karimi et al., 2020). The present study predicted air pollution changes that originated only from changes in 
households' consumption of energy. Since households generate about $60 \%$ of the total emission of CO (Energy, 2020), a 25\% decrease in CO level can be achieved with an approximately $42 \%$ decrease in households' consumption of energy (assuming that the $\mathrm{CO}$ emitted by non-household sectors remains unchanged). According to this study, households will reduce their consumption of energy by $42 \%$ if energy prices are increased by $180 \%$.

\subsection{Limitations of the present study}

This study's results for urban households are more precise as the CBI provides detailed price indices only for urban areas. The SCI calculates price indices for both urban and rural areas, but its detailed, commodity-specific indices are not available (SCI, 2020). Reviewing the SCI's overall and commodity group price indices, however, showed insignificant differences in prices between urban and rural areas during the period of this study (The SCI provides price indices for the HEIS standard categories of goods and services-namely, food and drinks, tobacco, clothes and shoes, housing and utilities, furniture and home goods, health, transportation, communication, entertainment, education, hotel and restaurants, miscellaneous, and durables.). Therefore, the results for rural households are not expected to be considerably imprecise.

Electricity was dropped from air pollution calculations. Household consumption of electricity does not create air pollution directly, but its production (which extensively relies on fossil fuel power plants in Iran) does contribute to air pollution. Hence, the predicted air pollution changes are underestimations of actual changes.

The reliability of this study's projections partly depends on the reliability of the projections of changes in the price of non-energy categories of goods and services. The latter projections assumed that an energy price hike would not noticeably change the approximately linear pattern of other prices after the energy price hike. The assumption accords with the recent experiences, but there is no guarantee that will hold when the next energy price hike takes place. Projecting for a short period (no more than one year, for example) is a way to limit the extent of this uncertainty.

The projections of this analysis assume that the economic conditions during the year before and the year after an energy price hike remain the same. Since the Iranian economy has experienced international sanctions in the past two decades, one implication of this assumption is that the county's sanction status remains unchanged during the one-year post-energy-price-hike period. In the presence of a change in sanctions' type and strength, one needs to adjust price and income trends. An approximation of such adjustments is beyond the scope of this study, as it needs an extensive study of the economic effect of past sanctions and projecting the impact of potential softening or tightening of sanctions.

\section{Conclusions and future prospects}

Price subsidy on fossil energy is distributed strikingly unequally and leads to inefficient use of energy and hence, to an avoidable mass in outdoor air pollution, which is a major risk factor for human health. Quantifying the relationship between energy price subsidy and human health needs the quantification of three links: (1) fossil energy price subsidy and energy consumption, (2) fossil energy consumption and air pollution, (3) air pollution and human health. Quantifying each link is challenging because of the difficulties of accounting for the human's preference and behavioral responses. As a part of a broad HIA plan to connect energy, environmental, and health policies, this study estimated the first two links.

While this study provided initial approximations for the third link, quantifying the relationship between the predicted air pollution changes and human health requires exclusive attention. Therefore, the immediate follow-up of this study is providing an in-depth analysis of the effects of the scenarios of fossil fuel energy price change on Iranians' health, measured by the all-cause and cause-specific burden of diseases, by age, gender, and location.

This study also highlights the significance of long-term strategies that intend to achieve the transition from allocating subsidies to unsustainable, environmentally-degrading fossil fuels to sustainably-produced renewable energy carriers. Therefore, another line of inquiry that emerges from this study is projecting the reduction in air pollution and gains in human health from reallocating the fossil fuel subsidies to the development of the infrastructures of the renewable energy industry (such as waste-oriented biofuels). Pro-poor redistribution of cutting fossil fuel subsidies is a very important complementary component for this strategy.

\section{Acknowledgements}

The authors would like to thank Maryam Karimi for the photo used in the Graphical Abstract.

\section{References}

[1] Ahadi, S,N.M., Roshani, M., 2018. Tehran air quality report 2017.

[2] Atamanov, A., Mostafavi, M.H., Salehi-Isfahani, D., Vishwanath, T. 2016. Constructing robust poverty trends in the Islamic Republic of Iran: 2008-14. The World Bank Group.

[3] Bank, J., Blundell, R., Lewbel, A., 1997. Quadratic Engel Curves and Consumer Demand. Review of Economics and Statistic. Econ. Papers. 79(4), 527-539.

[4] Bank, T.W., 2020. The World Bank, International Comparison Program Database. PPP conversion factor, private consumption (LCU per international \$) - Iran, Islamic Rep.

[5] Bayat, R., Ashrafi, K., Motlagh, M.S., Hassanvand, M.S., Daroudi, R., Fink, G., Künzli, N., 2019. Health impact and related cost of ambient air pollution in Tehran. Environ. Res. 176, 108547

[6] Cai, Y., Zhang, B., Ke, W., Feng, B., Lin, H., Xiao, J., Zeng, W., Li, X., Tao, J., Yang, Z., Ma, W., 2016. Associations of short-term and long-term exposure to ambient air pollutants with hypertension: a systematic review and meta-analysis. Hypertension. 68(1), 62-70

[7] CBI., 2020. Economic Research and Policy Department, Economic Time Series Database. Tehran, Iran

[8] Center, T.I.P.R., 2019. The IRI parliament research center. about energy subsidy in Iran: (1) the hidden subsidy. Topical Code 310 Serial Code 16652

[9] Coady, D., Parry, I., Le, N.P., Shang, B., 2019. Global fossil fue subsidies remain large: an update based on country-level estimates. IMF Working Pap. 19(89), 39

[10] Davis, L.W., 2017. The environmental cost of global fuel subsidies Energy J. 38(KAPSARC Special Issue)

[11] Deaton, A., Muellbauer, J., 1980a. An almost ideal demand system. Am. Econ. Rev. 70(3), 312-326.

[12] Deaton, A., Muellbauer, J., 1980b. Economics and consumer behavior, Cambridge university press.

[13] Dehghan, A., Khanjani, N., Bahrampour, A., Goudarzi, G., Yunesian, M., 2018. The relation between air pollution and respiratory deaths in Tehran, Iran-using generalized additive models. BMC Pulm. Med. 18(1), 49 .

[14] Del Granado, F.J.A., Coady, D., Gillingham, R., 2012. The unequal benefits of fuel subsidies: a review of evidence for developing countries. World Dev. 40(11), 2234-2248.

[15] Energy, I.M.O., 2020. Iran Ministry of Energy, Office of Planning and Macroeconomics of Electricity and Energy. Energy Balance Sheets. Tehran, Iran

[16] Enriquez, S., Larsen, B., Sánchez-Triana, E., 2018. Energy Subsidy Reform Assessment Framework: Local Environmental Externalities Due to Energy Price Subsidies-A Focus on Air Pollution and Health, World Bank

[17] Fassihi, F.G.R., 2019. Iran abruptly raises fuel prices, and protests erupt. New York Times.

[18] Ferreira, F.H., Chen, S., Dabalen, A., Dikhanov, Y., Hamadeh, N., Jolliffe, D., Narayan, A., Prydz, E.B., Revenga, A., Sangraula, P., Serajuddin, U., 2015. A global count of the extreme poor in 2012: data issues, methodology and initial results. The World Bank.

[19] Gahvari, F., Karimi, S.M., 2016. Export constraint and domestic fiscal reform: lessons from 2011 subsidy reform in Iran. Q. Rev. Econ. Finance. 60, 40-57

[20] GPP., 2019. GlobalPetrolPrices.com. Retail energy price data electricity prices, kWh, September 2019.

[21] GPP., 2020. GlobalPetrolPrices.com. Retail energy price data: gasoline prices, liter, 23-Mar-2020.

[22] Guarnieri, M., Balmes, J.R., 2014. Outdoor air pollution and asthma. The Lancet 383(9928), 1581-1592. 
[23] Haidar JI, K.S., 2020. Sanctions and household welfare: evidence from Iran.

[24] Karimi, S.M., Maziyaki, A., Moghadam, S.A., Jafarkhani, M., Zarei, H., Moradi-Lakeh, M., Pouran, H., 2020. Continuous exposure to ambient air pollution and chronic diseases: prevalence, burden, and economic costs. Rev. Environ. Health. 1(ahead-of-print).

[25] Kusch-Brandt, S., 2019. Urban Renewable Energy on the Upswing: A Spotlight on Renewable Energy in Cities in REN21's "Renewables 2019 Global Status Report". Multidisciplinary Digital Publishing Institute.

[26] Labandeira, X., Labeaga, J.M. and López-Otero, X., 2017. A metaanalysis on the price elasticity of energy demand. Energy Policy 102, 549568.

[27] Roth, G.A., Abate, D., Abate, K.H., Abay, S.M., Abbafati, C., Abbasi, N., Abbastabar, H., Abd-Allah, F., Abdela, J., Abdelalim, A., Abdollahpour, I., 2018. Global, regional, and national age-sex-specific mortality for 282 causes of death in 195 countries and territories, 19802017: a systematic analysis for the Global Burden of Disease Study 2017. The Lancet. 392(10159), 1736-1788.

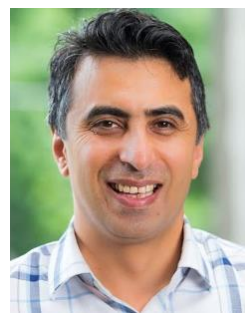

Dr. Seyed M. Karimi is a health economist and an Assistant Professor at the University of Louisville, School of Public Health and Information Sciences (SPHIS). He also serves as a public health policy advisor at the Louisville Metro Department of Public Health and the Wellness's (LMPHW) Center for Health Equity. His work sits at the intersection of microeconomics, statistics, and health policy. Health policy evaluation, modeling health care finance, earlylife shock analysis, environmental health, welfare analysis, and burden of disease estimation are the areas of his research.

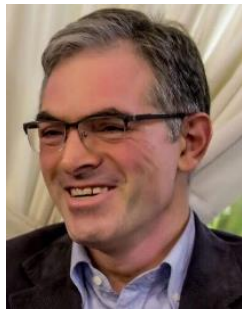

Dr. Maziar Moradi-Lakeh is an adjunct Professor at the Community and Family Medicine Department (Iran University of Medical Sciences). He has more than 15 years of experience in academic job and research in Iran and the United States. His experience is mainly related to the fields of health metrics and evaluation sciences, health economics and outcome research, disease epidemiology, and burden of disease. He has contributed to more than 200 peer-reviewed papers, as well as other publications such as clinical guidelines, policy documents, and educational books. His publications have been extensively cited and impacted health policies and programs.

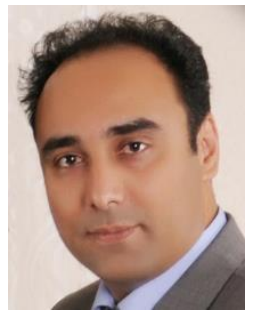

Dr. Majid Kermani is an Associate Professor at the Department of Environmental Health Engineering at the Iran University of Medical Sciences. He serves as a researcher at the Iran University of Medical Sciences' Research Center for Environmental Health Technology. His research interests include air pollution control, municipal wastewater collection, wastewater treatment, and disposal water quality and treatment.
[28] SCI., 2020. Statistical Center of Iran, Statistical Surveys: Household Expenditure and Income Survey. Tehran, Iran.

[29] SCI., 2020. Statistical Center of Iran. Price Indices of Consumption Goods and Services. Tehran, Iran.

[30] Sicard, P., Khaniabadi, Y.O., Perez, S., Gualtieri, M., De Marco, A. 2019. Effect of $\mathrm{O}_{3}, \mathrm{PM}_{10}$ and $\mathrm{PM}_{2.5}$ on cardiovascular and respiratory diseases in cities of France, Iran and Italy. Environ. Sci. Pollut. Res. 26(31), 32645-32665.

[31] Sørensen, M., Lühdorf, P., Ketzel, M., Andersen, Z.J., Tjønneland, A., Overvad, K., Raaschou-Nielsen, O., 2014. Combined effects of road traffic noise and ambient air pollution in relation to risk for stroke?. Environ. Res. 133, 49-55

[32] Turner, M.C., Krewski, D., Diver, W.R., Pope III, C.A., Burnett, R.T., Jerrett, M., Marshall, J.D., Gapstur, S.M., 2017. Ambient air pollution and cancer mortality in the cancer prevention study II. Environ. Health Perspect. 125(8), 087013.

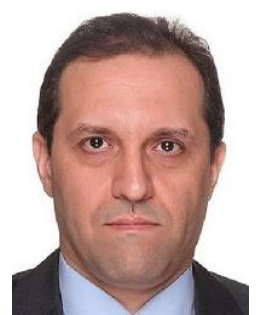

Dr. Seyed Abbas Motevalian is a Professor of epidemiology at the Iran University of Medical Sciences. He serves as a researcher at the Iran University of Medical Sciences' Research Center for Addiction and Risky Behaviors (ReCARB) and Psychosocial Health Research Institute (PHRI). He is also the Vice-Chancellor of Research and Technology of the Iran University of Medical Sciences. His research interests include substance abuse epidemiology, injury epidemiology, and occupational epidemiology.

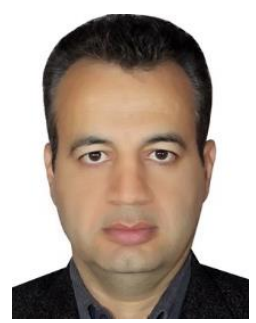

Dr. Seyed Reza Khatibi is an MD-MPH and $\mathrm{PhD}$ candidate in epidemiology at the Iran University of Medical Sciences in Tehran. He is also a research associate at the Torbat Heydariyeh University of Medical Sciences. He received his MD from the Iran University of Medical Sciences and his MPH from the Tehran University of Medical Sciences. Dr. Khatibi serves as a subject editor for the Journa of Torbat Heydariyeh University of Medical Sciences. His research interests include burden of diseases and health impact assessment. 


\section{Supplementary file}

Table S1.

Cross- and own-price elasticities for all income deciles in the pooled sample in 2016.

\begin{tabular}{|c|c|c|c|c|c|c|c|c|}
\hline & & \multicolumn{7}{|c|}{ Price change in: } \\
\hline & & Energy & $\begin{array}{c}\text { Energy- } \\
\text { consuming good }\end{array}$ & $\begin{array}{c}\text { Non-energy- } \\
\text { consuming good }\end{array}$ & Services & Housing & $\begin{array}{l}\text { Subsidized } \\
\text { food }\end{array}$ & $\begin{array}{l}\text { Unsubsidized } \\
\text { food }\end{array}$ \\
\hline \multicolumn{9}{|c|}{ The first (bottom) income decile } \\
\hline Consumption change in: $\rightarrow$ & $\begin{array}{l}\text { Energy } \\
\text { Energy-consuming good } \\
\text { Energy-consuming good } \\
\text { Services } \\
\text { Housing } \\
\text { Subsidized food } \\
\text { Unsubsidized food } \\
\end{array}$ & $\begin{array}{c}-0.67 \\
-3.74 \\
-0.26 \\
-0.02 \\
0.02 \\
0.09 \\
-0.08 \\
\end{array}$ & $\begin{array}{c}-0.11 \\
-1.81 \\
-0.19 \\
-0.11 \\
0.03 \\
0.04 \\
0.08 \\
\end{array}$ & $\begin{array}{c}-0.10 \\
-3.68 \\
-0.03 \\
-0.23 \\
0.05 \\
-0.13 \\
-0.05 \\
\end{array}$ & $\begin{array}{c}-0.02 \\
-3.77 \\
-0.47 \\
-0.51 \\
-0.02 \\
0.06 \\
-0.02 \\
\end{array}$ & $\begin{array}{c}-0.01 \\
-2.33 \\
-0.70 \\
-0.16 \\
-0.76 \\
-0.04 \\
0.03 \\
\end{array}$ & $\begin{array}{c}0.11 \\
0.72 \\
-0.55 \\
0.07 \\
-0.06 \\
-0.78 \\
-0.01 \\
\end{array}$ & $\begin{array}{c}-0.21 \\
2.01 \\
-0.80 \\
-0.07 \\
0.18 \\
0.10 \\
-0.99 \\
\end{array}$ \\
\hline \multicolumn{9}{|l|}{ The second income decile } \\
\hline Consumption change in: $\rightarrow$ & $\begin{array}{l}\text { Energy } \\
\text { Energy-consuming good } \\
\text { Energy-consuming good } \\
\text { Services } \\
\text { Housing } \\
\text { Subsidized food } \\
\text { Unsubsidized food } \\
\end{array}$ & $\begin{array}{c}-0.67 \\
-2.14 \\
-0.17 \\
-0.02 \\
0.02 \\
0.09 \\
-0.07 \\
\end{array}$ & $\begin{array}{c}-0.11 \\
-1.46 \\
-0.15 \\
-0.09 \\
0.04 \\
0.04 \\
0.08 \\
\end{array}$ & $\begin{array}{c}-0.09 \\
-2.11 \\
-0.19 \\
-0.19 \\
0.04 \\
-0.14 \\
-0.03 \\
\end{array}$ & $\begin{array}{c}-0.02 \\
-2.16 \\
-0.34 \\
-0.61 \\
-0.03 \\
0.06 \\
-0.02 \\
\end{array}$ & $\begin{array}{l}-0.01 \\
-1.33 \\
-0.39 \\
-0.16 \\
-0.78 \\
-0.06 \\
0.06 \\
\end{array}$ & $\begin{array}{c}0.11 \\
0.41 \\
-0.40 \\
0.05 \\
-0.09 \\
-0.78 \\
0.00 \\
\end{array}$ & $\begin{array}{c}-0.21 \\
1.15 \\
-0.48 \\
-0.08 \\
0.15 \\
0.09 \\
-0.96 \\
\end{array}$ \\
\hline \multicolumn{9}{|l|}{ The third income decile } \\
\hline Consumption change in: $\rightarrow$ & $\begin{array}{l}\text { Energy } \\
\text { Energy-consuming good } \\
\text { Energy-consuming good } \\
\text { Services } \\
\text { Housing } \\
\text { Subsidized food } \\
\text { Unsubsidized food }\end{array}$ & $\begin{array}{c}-0.65 \\
-1.53 \\
-0.14 \\
-0.02 \\
0.01 \\
0.10 \\
-0.07\end{array}$ & $\begin{array}{l}-0.12 \\
-1.33 \\
-0.12 \\
-0.09 \\
0.04 \\
0.05 \\
0.08\end{array}$ & $\begin{array}{c}-0.10 \\
-1.51 \\
-0.27 \\
-0.19 \\
0.03 \\
-0.15 \\
-0.03\end{array}$ & $\begin{array}{c}-0.02 \\
-1.54 \\
-0.29 \\
-0.62 \\
-0.04 \\
0.07 \\
-0.01\end{array}$ & $\begin{array}{c}0.00 \\
-0.95 \\
-0.28 \\
-0.16 \\
-0.82 \\
-0.07 \\
0.08 \\
\end{array}$ & $\begin{array}{c}0.12 \\
0.30 \\
-0.34 \\
0.05 \\
-0.10 \\
-0.75 \\
0.00\end{array}$ & $\begin{array}{c}-0.21 \\
0.82 \\
-0.36 \\
-0.09 \\
0.12 \\
0.09 \\
-0.95\end{array}$ \\
\hline \multicolumn{9}{|l|}{ The fourth income decile } \\
\hline Consumption change in: $\rightarrow$ & $\begin{array}{l}\text { Energy } \\
\text { Energy-consuming good } \\
\text { Energy-consuming good } \\
\text { Services } \\
\text { Housing } \\
\text { Subsidized food } \\
\text { Unsubsidized food } \\
\end{array}$ & $\begin{array}{c}-0.64 \\
-1.20 \\
-0.12 \\
-0.03 \\
0.01 \\
0.10 \\
-0.07 \\
\end{array}$ & $\begin{array}{c}-0.12 \\
-1.26 \\
-0.11 \\
-0.09 \\
0.03 \\
0.05 \\
0.08 \\
\end{array}$ & $\begin{array}{c}-0.10 \\
-1.18 \\
-0.31 \\
-0.18 \\
0.02 \\
-0.17 \\
-0.03 \\
\end{array}$ & $\begin{array}{c}-0.02 \\
-1.21 \\
-0.26 \\
-0.64 \\
-0.05 \\
0.08 \\
-0.01 \\
\end{array}$ & $\begin{array}{c}0.00 \\
-0.75 \\
-0.21 \\
-0.16 \\
-0.84 \\
-0.08 \\
0.09 \\
\end{array}$ & $\begin{array}{c}0.13 \\
0.23 \\
-0.31 \\
0.04 \\
-0.10 \\
-0.73 \\
0.00 \\
\end{array}$ & $\begin{array}{c}-0.22 \\
0.65 \\
-0.29 \\
-0.09 \\
0.10 \\
0.10 \\
-0.94 \\
\end{array}$ \\
\hline \multicolumn{9}{|l|}{ The fifth income decile } \\
\hline Consumption change in: $\rightarrow$ & $\begin{array}{l}\text { Energy } \\
\text { Energy-consuming good } \\
\text { Energy-consuming good } \\
\text { Services } \\
\text { Housing } \\
\text { Subsidized food } \\
\text { Unsubsidized food } \\
\end{array}$ & $\begin{array}{c}-0.66 \\
-1.02 \\
-0.11 \\
-0.03 \\
0.00 \\
0.11 \\
-0.07 \\
\end{array}$ & $\begin{array}{c}-0.12 \\
-1.22 \\
-0.10 \\
-0.09 \\
0.03 \\
0.05 \\
0.08 \\
\end{array}$ & $\begin{array}{c}-0.10 \\
-1.01 \\
-0.34 \\
-0.18 \\
0.01 \\
-0.19 \\
-0.02 \\
\end{array}$ & $\begin{array}{c}-0.02 \\
-1.03 \\
-0.23 \\
-0.65 \\
-0.05 \\
0.08 \\
-0.01 \\
\end{array}$ & $\begin{array}{c}0.00 \\
-0.64 \\
-0.17 \\
-0.16 \\
-0.86 \\
-0.09 \\
0.09 \\
\end{array}$ & $\begin{array}{c}0.12 \\
0.20 \\
-0.28 \\
0.04 \\
-0.11 \\
-0.71 \\
0.00 \\
\end{array}$ & $\begin{array}{c}-0.21 \\
0.55 \\
-0.25 \\
-0.09 \\
0.09 \\
0.10 \\
-0.93 \\
\end{array}$ \\
\hline \multicolumn{9}{|l|}{ The sixth income decile } \\
\hline Consumption change in: $\rightarrow$ & $\begin{array}{l}\text { Energy } \\
\text { Energy-consuming good } \\
\text { Energy-consuming good } \\
\text { Services } \\
\text { Housing } \\
\text { Subsidized food } \\
\text { Unsubsidized food } \\
\end{array}$ & $\begin{array}{c}-0.64 \\
-0.86 \\
-0.10 \\
-0.03 \\
0.00 \\
0.12 \\
-0.07 \\
\end{array}$ & $\begin{array}{c}-0.12 \\
-1.19 \\
-0.09 \\
-0.09 \\
0.03 \\
0.06 \\
0.08 \\
\end{array}$ & $\begin{array}{c}-0.10 \\
-0.85 \\
-0.37 \\
-0.18 \\
0.01 \\
-0.20 \\
-0.02 \\
\end{array}$ & $\begin{array}{c}-0.02 \\
-0.87 \\
-0.21 \\
-0.65 \\
-0.05 \\
0.09 \\
-0.01 \\
\end{array}$ & $\begin{array}{c}0.00 \\
-0.54 \\
-0.13 \\
-0.17 \\
-0.88 \\
-0.10 \\
0.10 \\
\end{array}$ & $\begin{array}{c}0.13 \\
0.17 \\
-0.26 \\
0.04 \\
-0.11 \\
-0.69 \\
0.00 \\
\end{array}$ & $\begin{array}{c}-0.22 \\
0.46 \\
-0.21 \\
-0.10 \\
0.07 \\
0.11 \\
-0.92 \\
\end{array}$ \\
\hline \multicolumn{9}{|l|}{ The seventh income decile } \\
\hline Consumption change in: $\rightarrow$ & $\begin{array}{l}\text { Energy } \\
\text { Energy-consuming good } \\
\text { Energy-consuming good } \\
\text { Services } \\
\text { Housing } \\
\text { Subsidized food } \\
\text { Unsubsidized food }\end{array}$ & $\begin{array}{c}-0.63 \\
-0.64 \\
-0.09 \\
-0.03 \\
0.00 \\
0.13 \\
-0.07 \\
\end{array}$ & $\begin{array}{c}-0.12 \\
-1.14 \\
-0.08 \\
-0.08 \\
0.02 \\
0.06 \\
0.08 \\
\end{array}$ & $\begin{array}{c}-0.10 \\
-0.63 \\
-0.39 \\
-0.18 \\
0.00 \\
-0.23 \\
-0.02 \\
\end{array}$ & $\begin{array}{c}-0.02 \\
-0.64 \\
-0.19 \\
-0.66 \\
-0.06 \\
0.10 \\
-0.01 \\
\end{array}$ & $\begin{array}{c}0.01 \\
-0.40 \\
-0.10 \\
-0.17 \\
-0.90 \\
-0.12 \\
0.11 \\
\end{array}$ & $\begin{array}{c}0.13 \\
0.12 \\
-0.25 \\
0.04 \\
-0.11 \\
-0.65 \\
0.00 \\
\end{array}$ & $\begin{array}{c}-0.22 \\
0.34 \\
-0.17 \\
-0.10 \\
0.05 \\
0.12 \\
-0.92 \\
\end{array}$ \\
\hline \multicolumn{9}{|l|}{ The eighth income decile } \\
\hline Consumption change in: $\rightarrow$ & $\begin{array}{l}\text { Energy } \\
\text { Energy-consuming good } \\
\text { Energy-consuming good } \\
\text { Services } \\
\text { Housing } \\
\text { Subsidized food } \\
\text { Unsubsidized food }\end{array}$ & $\begin{array}{c}-0.61 \\
-0.49 \\
-0.08 \\
-0.03 \\
-0.01 \\
0.15 \\
-0.06\end{array}$ & $\begin{array}{l}-0.13 \\
-1.11 \\
-0.06 \\
-0.09 \\
0.02 \\
0.07 \\
0.09\end{array}$ & $\begin{array}{l}-0.10 \\
-0.48 \\
-0.44 \\
-0.19 \\
-0.01 \\
-0.26 \\
-0.01\end{array}$ & $\begin{array}{c}-0.02 \\
-0.49 \\
-0.17 \\
-0.66 \\
-0.06 \\
0.11 \\
0.00\end{array}$ & $\begin{array}{c}0.01 \\
-0.30 \\
-0.06 \\
-0.18 \\
-0.92 \\
-0.14 \\
0.12\end{array}$ & $\begin{array}{c}0.14 \\
0.09 \\
-0.22 \\
0.04 \\
-0.11 \\
-0.61 \\
0.00\end{array}$ & $\begin{array}{c}-0.23 \\
0.26 \\
-0.13 \\
-0.11 \\
0.04 \\
0.13 \\
-0.91\end{array}$ \\
\hline
\end{tabular}


Table S1.

continued.

\begin{tabular}{|c|c|c|c|c|c|c|c|c|}
\hline & & \multicolumn{7}{|c|}{ Price change in: } \\
\hline & & Energy & $\begin{array}{c}\text { Energy- } \\
\text { consuming good }\end{array}$ & $\begin{array}{l}\text { Non-energy- } \\
\text { consuming good }\end{array}$ & Services & Housing & $\begin{array}{l}\text { Subsidized } \\
\text { food }\end{array}$ & $\begin{array}{l}\text { Unsubsidized } \\
\text { food }\end{array}$ \\
\hline \multicolumn{9}{|l|}{ The nineth income decile } \\
\hline \multirow{7}{*}{ Consumption change in: $\rightarrow$} & Energy & -0.59 & -0.14 & -0.11 & -0.02 & 0.01 & 0.14 & -0.24 \\
\hline & Energy-consuming good & -0.28 & -1.06 & -0.28 & -0.29 & -0.18 & 0.05 & 0.15 \\
\hline & Energy-consuming good & -0.06 & -0.05 & -0.48 & -0.14 & -0.02 & -0.20 & -0.09 \\
\hline & Services & -0.03 & -0.09 & -0.19 & -0.67 & -0.18 & 0.04 & -0.11 \\
\hline & Housing & -0.01 & 0.01 & -0.02 & -0.07 & -0.94 & -0.11 & 0.01 \\
\hline & Subsidized food & 0.18 & 0.08 & -0.32 & 0.13 & -0.17 & -0.52 & 0.15 \\
\hline & Unsubsidized food & -0.07 & 0.10 & -0.01 & 0.00 & 0.14 & 0.01 & -0.89 \\
\hline \multicolumn{9}{|l|}{ The tenth income decile } \\
\hline \multirow{7}{*}{ Consumption change in: $\rightarrow$} & Energy & -0.47 & -0.17 & -0.13 & -0.02 & 0.03 & 0.19 & -0.30 \\
\hline & Energy-consuming good & -0.10 & -1.02 & -0.10 & -0.10 & -0.06 & 0.02 & 0.05 \\
\hline & Energy-consuming good & -0.05 & -0.03 & -0.43 & -0.12 & 0.06 & -0.20 & -0.03 \\
\hline & Services & -0.03 & -0.10 & -0.21 & -0.66 & -0.22 & 0.04 & -0.13 \\
\hline & Housing & -0.02 & -0.01 & -0.06 & -0.10 & -1.01 & -0.11 & -0.04 \\
\hline & Subsidized food & 0.27 & 0.12 & -0.51 & 0.19 & -0.30 & -0.26 & 0.20 \\
\hline & Unsubsidized food & -0.07 & 0.12 & 0.01 & 0.01 & 0.20 & 0.01 & -0.85 \\
\hline
\end{tabular}


Table S2.

Percentage change in energy consumption by income decile under different scenarios of energy price hike.

\begin{tabular}{|c|c|c|c|c|c|c|c|c|c|c|c|c|c|c|c|c|c|c|c|c|}
\hline \multirow{2}{*}{$\begin{array}{l}\text { Income } \\
\text { decile }\end{array}$} & \multicolumn{20}{|c|}{ Scenarios of energy price hike (\% Increase): $\downarrow$} \\
\hline & 10 & 20 & 30 & 40 & $\mathbf{5 0}$ & 60 & 70 & 80 & 90 & 100 & 110 & 120 & 130 & 140 & 150 & 160 & 170 & 180 & 190 & 200 \\
\hline \multicolumn{21}{|l|}{ Urban households } \\
\hline 1 & -3 & -7 & -11 & -14 & -17 & -20 & -23 & -25 & -28 & -30 & -32 & -34 & -35 & -37 & -39 & -40 & -42 & -43 & -44 & -45 \\
\hline 2 & -2 & -6 & -10 & -13 & -16 & -19 & -22 & -25 & -27 & -29 & -31 & -33 & -35 & -37 & -38 & -40 & -41 & -43 & -44 & -45 \\
\hline 3 & -2 & -6 & -10 & -13 & -16 & -19 & -22 & -25 & -27 & -29 & -31 & -33 & -35 & -37 & -38 & -40 & -41 & -43 & -44 & -45 \\
\hline 4 & -3 & -7 & -10 & -14 & -17 & -20 & -23 & -25 & -27 & -30 & -32 & -34 & -35 & -37 & -39 & -40 & -42 & -43 & -44 & -45 \\
\hline 5 & -3 & -7 & -11 & -14 & -17 & -20 & -23 & -25 & -28 & -30 & -32 & -34 & -35 & -37 & -39 & -40 & -42 & -43 & -44 & -45 \\
\hline 6 & -3 & -7 & -11 & -14 & -17 & -20 & -23 & -25 & -28 & -30 & -32 & -34 & -36 & -37 & -39 & -40 & -42 & -43 & -44 & -46 \\
\hline 7 & -3 & -7 & -11 & -14 & -17 & -20 & -23 & -25 & -28 & -30 & -32 & -34 & -36 & -37 & -39 & -40 & -42 & -43 & -44 & -46 \\
\hline 8 & -4 & -7 & -11 & -14 & -17 & -20 & -23 & -25 & -28 & -30 & -32 & -34 & -36 & -37 & -39 & -40 & -42 & -43 & -44 & -45 \\
\hline 9 & -4 & -8 & -11 & -15 & -18 & -20 & -23 & -25 & -28 & -30 & -32 & -34 & -35 & -37 & -39 & -40 & -42 & -43 & -44 & -45 \\
\hline 10 & -2 & -6 & -9 & -12 & -15 & -18 & -21 & -23 & -25 & -27 & -29 & -31 & -33 & -35 & -36 & -38 & -39 & -41 & -42 & -43 \\
\hline Average household & -3 & -7 & -11 & -14 & -17 & -20 & -23 & -25 & -27 & -30 & -32 & -33 & -35 & -37 & -39 & -40 & -41 & -43 & -44 & -45 \\
\hline \multicolumn{21}{|l|}{ Rural households } \\
\hline 1 & 5 & 1 & -3 & -7 & -10 & -13 & -16 & -19 & -21 & -23 & -26 & -28 & -30 & -31 & -33 & -35 & -36 & -38 & -39 & -40 \\
\hline 2 & 3 & -1 & -5 & -9 & -12 & -15 & -18 & -21 & -23 & -26 & -28 & -30 & -32 & -33 & -35 & -37 & -38 & -40 & -41 & -42 \\
\hline 3 & 3 & -2 & -6 & -9 & -13 & -16 & -18 & -21 & -24 & -26 & -28 & -30 & -32 & -34 & -35 & -37 & -38 & -40 & -41 & -43 \\
\hline 4 & 2 & -2 & -6 & -10 & -13 & -16 & -19 & -22 & -24 & -26 & -28 & -30 & -32 & -34 & -36 & -37 & -39 & -40 & -42 & -43 \\
\hline 5 & 2 & -2 & -6 & -9 & -13 & -16 & -19 & -21 & -24 & -26 & -28 & -30 & -32 & -34 & -36 & -37 & -39 & -40 & -41 & -43 \\
\hline 6 & 1 & -3 & -7 & -10 & -13 & -17 & -19 & -22 & -24 & -27 & -29 & -31 & -33 & -34 & -36 & -38 & -39 & -41 & -42 & -43 \\
\hline 7 & 1 & -3 & -7 & -11 & -14 & -17 & -20 & -22 & -25 & -27 & -29 & -31 & -33 & -35 & -36 & -38 & -39 & -41 & -42 & -43 \\
\hline 8 & 0 & -4 & -8 & -11 & -14 & -17 & -20 & -23 & -25 & -27 & -29 & -31 & -33 & -35 & -37 & -38 & -40 & -41 & -42 & -44 \\
\hline 9 & -1 & -5 & -9 & -12 & -15 & -18 & -21 & -24 & -26 & -28 & -30 & -32 & -34 & -36 & -37 & -39 & -40 & -42 & -43 & -44 \\
\hline 10 & -2 & -6 & -9 & -13 & -16 & -18 & -21 & -24 & -26 & -28 & -30 & -32 & -34 & -36 & -37 & -39 & -40 & -41 & -43 & -44 \\
\hline Average household & 0 & -4 & -8 & -11 & -14 & -17 & -20 & -23 & -25 & -27 & -30 & -32 & -33 & -35 & -37 & -38 & -40 & -41 & -42 & -44 \\
\hline
\end{tabular}


Table S3.

Predicted decrease in total emission of air pollutants by source under all scenarios of energy price hike (numbers in tons)

\begin{tabular}{|c|c|c|c|c|c|c|c|}
\hline & CO & $\mathrm{CO}_{2}$ & $\mathrm{NO}_{\mathrm{x}}$ & $\mathbf{N}_{2} \mathrm{O}$ & $\mathrm{SO}_{\mathbf{x}}$ & $\mathrm{CH}_{4}$ & SPM \\
\hline \multicolumn{8}{|c|}{$10 \%$ Increase in energy price } \\
\hline Gasoline & -87994 & -598138 & -3394 & -28 & -377 & -285 & -327 \\
\hline Diesel & 0 & -4813 & -9 & 0 & -27 & 0 & -2 \\
\hline Natural gas & -207 & -1672757 & -1547 & -3 & -6 & -30 & -148 \\
\hline LNG & -211 & -96823 & -21 & 0 & 0 & -2 & 0 \\
\hline Kerosene & -36 & -118722 & -23 & -1 & -109 & -5 & 0 \\
\hline Total & -88448 & -2491253 & -4993 & -32 & -520 & -321 & -476 \\
\hline \multicolumn{8}{|c|}{$20 \%$ Increase in energy price } \\
\hline Gasoline & -314164 & -2135521 & -12118 & -99 & -1346 & -1017 & -1167 \\
\hline Diesel & -1 & -17183 & -30 & 0 & -97 & -1 & -6 \\
\hline Natural gas & -740 & -5972209 & -5523 & -11 & -22 & -106 & -527 \\
\hline LNG & -753 & -345686 & -75 & -1 & -2 & -5 & 0 \\
\hline Kerosene & -127 & -423871 & -81 & -4 & -391 & -18 & 0 \\
\hline Total & -315785 & -8894470 & -17828 & -113 & -1858 & -1147 & -1700 \\
\hline \multicolumn{8}{|c|}{$30 \%$ Increase in energy price } \\
\hline Gasoline & -523524 & -3558642 & -20193 & -164 & -2244 & -1695 & -1944 \\
\hline Diesel & -2 & -28633 & -51 & 0 & -162 & -1 & -10 \\
\hline Natural gas & -1233 & -9952118 & -9204 & -18 & -37 & -177 & -879 \\
\hline LNG & -1255 & -576054 & -125 & -1 & -3 & -9 & 0 \\
\hline Kerosene & -212 & -706341 & -136 & -6 & -651 & -29 & 0 \\
\hline Total & -526226 & -14821788 & -29709 & -189 & -3096 & -1912 & -2834 \\
\hline \multicolumn{8}{|c|}{$40 \%$ Increase in energy price } \\
\hline Gasoline & -717203 & -4875163 & -27664 & -225 & -3074 & -2322 & -2664 \\
\hline Diesel & -3 & -39226 & -70 & 0 & -221 & -2 & -14 \\
\hline Natural gas & -1690 & -13633907 & -12609 & -24 & -50 & -243 & -1204 \\
\hline LNG & -1719 & -789165 & -172 & -1 & -4 & -13 & 0 \\
\hline Kerosene & -290 & -967651 & -186 & -8 & -892 & -40 & 0 \\
\hline Total & -720904 & -20305113 & -40700 & -259 & -4241 & -2619 & -3882 \\
\hline \multicolumn{8}{|c|}{$50 \%$ Increase in energy price } \\
\hline Gasoline & -896503 & -6093954 & -34579 & -281 & -3842 & -2902 & -3330 \\
\hline Diesel & -3 & -49033 & -87 & 0 & -277 & -2 & -17 \\
\hline Natural gas & -2112 & -17042383 & -15761 & -30 & -63 & -304 & -1505 \\
\hline LNG & -2149 & -986456 & -215 & -2 & -5 & -16 & 0 \\
\hline Kerosene & -362 & -1209564 & -232 & -10 & -1115 & -50 & 0 \\
\hline Total & -901130 & -25381389 & -50874 & -324 & -5301 & -3274 & -4852 \\
\hline \multicolumn{8}{|c|}{$60 \%$ Increase in energy price } \\
\hline Gasoline & -1062737 & -7223926 & -40991 & -334 & -4555 & -3440 & -3947 \\
\hline Diesel & -4 & -58125 & -103 & 0 & -328 & -2 & -21 \\
\hline Natural gas & -2504 & -20202471 & -18683 & -36 & -75 & -360 & -1784 \\
\hline LNG & -2547 & -1169370 & -255 & -2 & -6 & -19 & 0 \\
\hline Kerosene & -429 & -1433848 & -275 & -12 & -1321 & -60 & 0 \\
\hline Total & -1068222 & -30087740 & -60308 & -384 & -6284 & -3881 & -5752 \\
\hline
\end{tabular}


Table S3.

Continued.

\begin{tabular}{|c|c|c|c|c|c|c|c|}
\hline & Co & $\mathrm{CO}_{2}$ & $\mathrm{NO}_{\mathrm{x}}$ & $\mathbf{N}_{2} \mathrm{O}$ & SOx & $\mathbf{C H}_{4}$ & SPM \\
\hline \multicolumn{8}{|c|}{$70 \%$ Increase in energy price } \\
\hline Gasoline & -1217145 & -8273509 & -46947 & -382 & -5216 & -3940 & -4521 \\
\hline Diesel & -5 & -66570 & -118 & -1 & -376 & -3 & -24 \\
\hline Natural gas & -2867 & -23137739 & -21398 & -41 & -86 & -412 & -2043 \\
\hline LNG & -2917 & -1339270 & -292 & -2 & -6 & -21 & 0 \\
\hline Kerosene & -492 & -1642175 & -315 & -14 & -1514 & -68 & 0 \\
\hline Total & -1223426 & -34459264 & -69070 & -440 & -7197 & -4445 & -6588 \\
\hline \multicolumn{8}{|c|}{$80 \%$ Increase in energy price } \\
\hline Gasoline & -1360864 & -9250430 & -52490 & -427 & -5832 & -4405 & -5055 \\
\hline Diesel & -5 & -74431 & -132 & -1 & -420 & -3 & -26 \\
\hline Natural gas & -3206 & -25869801 & -23924 & -46 & -96 & -461 & -2285 \\
\hline LNG & -3262 & -1497409 & -326 & -2 & -7 & -24 & 0 \\
\hline Kerosene & -550 & -1836080 & -353 & -15 & -1692 & -77 & 0 \\
\hline Total & -1367886 & -38528151 & -77226 & -491 & -8047 & -4969 & -7366 \\
\hline \multicolumn{8}{|c|}{$\mathbf{9 0 \%}$ Increase in energy price } \\
\hline Gasoline & -1494918 & -10161661 & -57661 & -469 & -6407 & -4839 & -5552 \\
\hline Diesel & -6 & -81763 & -145 & -1 & -461 & -3 & -29 \\
\hline Natural gas & -3522 & -28418155 & -26281 & -51 & -105 & -507 & -2510 \\
\hline LNG & -3583 & -1644914 & -358 & -3 & -8 & -26 & 0 \\
\hline Kerosene & -604 & -2016947 & -387 & -17 & -1859 & -84 & 0 \\
\hline Total & -1502633 & -42323440 & -84833 & -540 & -8840 & -5459 & -8091 \\
\hline \multicolumn{8}{|c|}{$100 \%$ Increase in energy price } \\
\hline Gasoline & -1620226 & -11013439 & -62494 & -509 & -6944 & -5245 & -6018 \\
\hline Diesel & -6 & -88616 & -157 & -1 & -500 & -4 & -31 \\
\hline Natural gas & -3817 & -30800241 & -28484 & -55 & -114 & -549 & -2720 \\
\hline LNG & -3883 & -1782795 & -388 & -3 & -8 & -28 & 0 \\
\hline Kerosene & -655 & -2186013 & -420 & -18 & -2015 & -91 & 0 \\
\hline Total & -1628587 & -45871104 & -91944 & -585 & -9581 & -5917 & -8770 \\
\hline \multicolumn{8}{|c|}{$110 \%$ Increase in energy price } \\
\hline Gasoline & -1737604 & -11811315 & -67022 & -545 & -7447 & -5624 & -6454 \\
\hline Diesel & -7 & -95036 & -169 & -1 & -536 & -4 & -34 \\
\hline Natural gas & -4093 & -33031586 & -30548 & -59 & -122 & -589 & -2917 \\
\hline LNG & -4165 & -1911951 & -416 & -3 & -9 & -30 & 0 \\
\hline Kerosene & -702 & -2344380 & -450 & -19 & -2161 & -98 & 0 \\
\hline Total & -1746571 & -49194269 & -98605 & -627 & -10275 & -6345 & -9405 \\
\hline \multicolumn{8}{|c|}{$120 \%$ Increase in energy price } \\
\hline Gasoline & -1847779 & -12560225 & -71271 & -580 & -7919 & -5981 & -6863 \\
\hline Diesel & -7 & -101062 & -179 & -1 & -570 & -4 & -36 \\
\hline Natural gas & -4353 & -35125991 & -32485 & -63 & -130 & -626 & -3102 \\
\hline LNG & -4429 & -2033180 & -443 & -3 & -10 & -32 & 0 \\
\hline Kerosene & -747 & -2493028 & -479 & -21 & -2298 & -104 & 0 \\
\hline Total & -1857315 & -52313486 & -104857 & -667 & -10926 & -6747 & -10001 \\
\hline
\end{tabular}


Table S3.

Continued.

\begin{tabular}{|c|c|c|c|c|c|c|c|}
\hline & $\mathrm{CO}$ & $\mathrm{CO}_{2}$ & NO $_{x}$ & $\mathbf{N}_{2} \mathrm{O}$ & SO $_{x}$ & $\mathrm{CH}_{4}$ & SPM \\
\hline \multicolumn{8}{|c|}{$130 \%$ Increase in energy price } \\
\hline Gasoline & -1951395 & -13264552 & -75268 & -613 & -8363 & -6316 & -7248 \\
\hline Diesel & -8 & -106729 & -189 & -1 & -602 & -4 & -38 \\
\hline Natural gas & -4597 & -37095716 & -34306 & -66 & -137 & -661 & -3276 \\
\hline LNG & -4677 & -2147193 & -468 & -3 & -10 & -34 & 0 \\
\hline Kerosene & -789 & -2632827 & -506 & -22 & -2427 & -110 & 0 \\
\hline Total & -1961465 & -55247017 & -110737 & -705 & -11539 & -7126 & -10562 \\
\hline \multicolumn{8}{|c|}{$140 \%$ Increase in energy price } \\
\hline Gasoline & -2049026 & -13928195 & -79034 & -643 & -8781 & -6633 & -7611 \\
\hline Diesel & -8 & -112069 & -199 & -1 & -632 & -5 & -40 \\
\hline Natural gas & -4827 & -38951664 & -36022 & -69 & -144 & -694 & -3440 \\
\hline LNG & -4911 & -2254620 & -491 & -4 & -11 & -36 & 0 \\
\hline Kerosene & -828 & -2764551 & -531 & -23 & -2548 & -115 & 0 \\
\hline Total & -2059600 & -58011099 & -116277 & -740 & -12116 & -7482 & -11090 \\
\hline \multicolumn{8}{|c|}{$150 \%$ Increase in energy price } \\
\hline Gasoline & -2141183 & -14554626 & -82588 & -672 & -9176 & -6931 & -7953 \\
\hline Diesel & -8 & -117109 & -208 & -1 & -661 & -5 & -42 \\
\hline Natural gas & -5044 & -40703544 & -37643 & -72 & -150 & -726 & -3595 \\
\hline LNG & -5132 & -2356023 & -513 & -4 & -11 & -37 & 0 \\
\hline Kerosene & -865 & -2888889 & -555 & -24 & -2663 & -120 & 0 \\
\hline Total & -2152232 & -60620192 & -121507 & -773 & -12661 & -7819 & -11589 \\
\hline \multicolumn{8}{|c|}{$160 \%$ Increase in energy price } \\
\hline Gasoline & -2228320 & -15146942 & -85950 & -699 & -9550 & -7213 & -8277 \\
\hline Diesel & -9 & -121875 & -216 & -1 & -688 & -5 & -43 \\
\hline Natural gas & -5249 & -42360018 & -39175 & -75 & -157 & -755 & -3741 \\
\hline LNG & -5341 & -2451904 & -534 & -4 & -12 & -39 & 0 \\
\hline Kerosene & -901 & -3006455 & -577 & -25 & -2771 & -125 & 0 \\
\hline Total & -2239820 & -63087194 & -126452 & -805 & -13177 & -8137 & -12061 \\
\hline \multicolumn{8}{|c|}{$170 \%$ Increase in energy price } \\
\hline Gasoline & -2310846 & -15707911 & -89133 & -725 & -9904 & -7480 & -8583 \\
\hline Diesel & -9 & -126389 & -224 & -1 & -713 & -5 & -45 \\
\hline Natural gas & -5444 & -43928827 & -40625 & -78 & -162 & -783 & -3880 \\
\hline LNG & -5539 & -2542711 & -554 & -4 & -12 & -40 & 0 \\
\hline Kerosene & -934 & -3117800 & -599 & -26 & -2874 & -130 & 0 \\
\hline Total & -2322772 & -65423638 & -131135 & -834 & -13665 & -8438 & -12508 \\
\hline \multicolumn{8}{|c|}{$180 \%$ Increase in energy price } \\
\hline Gasoline & -2389126 & -16240014 & -92152 & -750 & -10239 & -7733 & -8874 \\
\hline Diesel & -9 & -130670 & -232 & -1 & -737 & -5 & -46 \\
\hline Natural gas & -5628 & -45416910 & -42002 & -81 & -168 & -810 & -4011 \\
\hline LNG & -5726 & -2628845 & -573 & -4 & -12 & -42 & 0 \\
\hline Kerosene & -965 & -3223415 & -619 & -27 & -2971 & -134 & 0 \\
\hline Total & -2401455 & -67639854 & -135577 & -863 & -14127 & -8724 & -12931 \\
\hline
\end{tabular}


Table S3.

Continued.

\begin{tabular}{|c|c|c|c|c|c|c|c|}
\hline & CO & $\mathrm{CO}_{2}$ & $\mathrm{NO}_{\mathrm{x}}$ & $\mathbf{N}_{2} \mathrm{O}$ & SO $_{x}$ & $\mathrm{CH}_{4}$ & SPM \\
\hline \multicolumn{8}{|c|}{$190 \%$ Increase in energy price } \\
\hline Gasoline & -2463487 & -16745479 & -95020 & -773 & -10558 & -7974 & -9150 \\
\hline Diesel & -10 & -134737 & -239 & -1 & -760 & -5 & -48 \\
\hline Natural gas & -5803 & -46830495 & -43309 & -83 & -173 & -835 & -4136 \\
\hline LNG & -5904 & -2710667 & -590 & -4 & -13 & -43 & 0 \\
\hline Kerosene & -996 & -3323742 & -638 & -28 & -3063 & -139 & 0 \\
\hline Total & -2476200 & -69745120 & -139797 & -890 & -14567 & -8996 & -13334 \\
\hline \multicolumn{8}{|c|}{$200 \%$ Increase in energy price } \\
\hline Gasoline & -2534224 & -17226311 & -97749 & -795 & -10861 & -8203 & -9413 \\
\hline Diesel & -10 & -138606 & -246 & -1 & -782 & -6 & -49 \\
\hline Natural gas & -5970 & -48175191 & -44552 & -86 & -178 & -859 & -4255 \\
\hline LNG & -6074 & -2788501 & -607 & -4 & -13 & -44 & 0 \\
\hline Kerosene & -1024 & -3419181 & -657 & -28 & -3151 & -143 & 0 \\
\hline Total & -2547301 & -71747789 & -143811 & -915 & -14985 & -9254 & -13717 \\
\hline
\end{tabular}




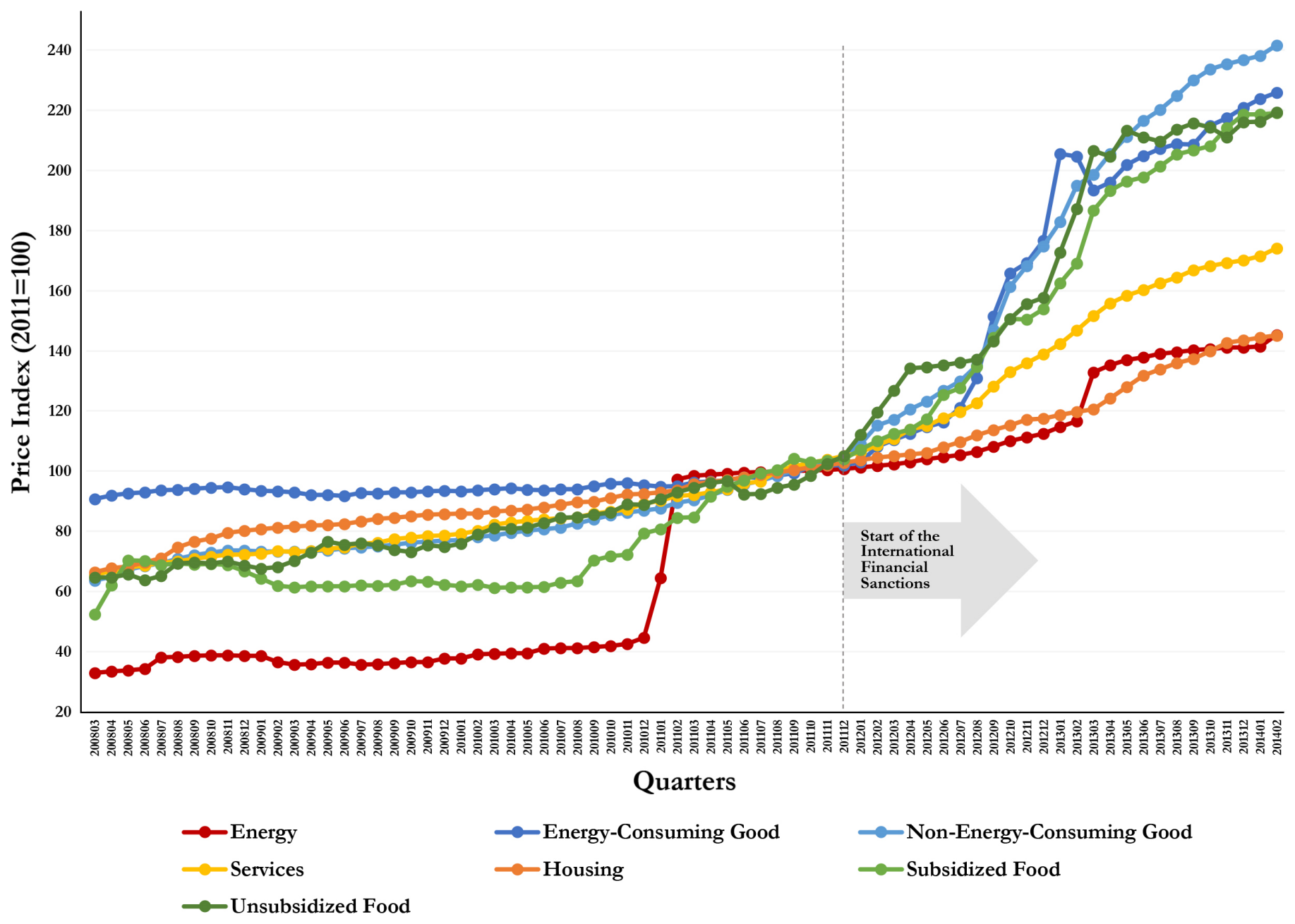

Fig. S1. Price indices of the seven categories of goods and services before and after the 2011 subsidy reform (2011=100). 